Working Papers of the Global Economic History Network (GEHN) No. $23 / 06$

\title{
The Spanish Empire and Its Legacy: Fiscal Re-distribution and Political Conflict in Colonial and Post-Colonial Spanish America
}

\author{
Regina Grafe \\ $\&$ \\ Maria Alejandra Irigoin
}

(C) Regina Grafe \& Maria Alejandra Irigoin

Department of Economic History

London School of Economics 


\section{千年之求索}

This paper was presented at the Seventh GEHN Conference, Istanbul, Turkey (11-12 ${ }^{\text {th }}$ September, 2005), funded by a Leverhulme Trust Grant: "A Millenium of Material Progress"

For more information about the participants and activities of GEHN, go to http://www.Ise.ac.uk/collections/economicHistory/GEHN/Default.htm

Department of Economic History London School of Economics Houghton Street London, WC2A 2AE

Tel: +44 (0) 2079557860

Fax: $\quad$ +44 (0) 2079557730 


\section{The Spanish Empire and its Legacy: Fiscal Re-distribution and Political Conflict in Colonial and Post-Colonial Spanish America*}

Regina Grafe \& Maria Alejandra Irigoin

As part of an endeavour to explain the divergence in incomes per capita between North and South America new institutional economics (NIE) and economic history have attempted in recent years to realize the potential effort for illumination derivable from comparisons of the heritage of their colonial institutions. As developed by North and his school these accounts of the institutional differences in the Americas are the offspring of similar (and we believe equally flawed) accounts for the divergence between Britain and the mainland of Europe - the latter afflicted by institutions epitomized by their inefficiencies compared with an entirely superior set of Anglo-Saxon institutions which promoted and sustained Britain's successful trajectory to the First Industrial Revolution. ${ }^{1}$

In contrast to the original NIE narrative, another view developed by a group pf North American economic historians and economists prefers to emphasise the role of factor endowments as a foundational basis for both economic and institutional divergence between North and South America over the $19^{\text {th }}$ and $20^{\text {th }}$ centuries. In its origin, this literature argues that the

\footnotetext{
* The authors would like to thank participants at the Global Economic History Workshop, Istanbul, 2005 and the NY Latin American History Workshop, Columbia University 2005 for comments and criticisms. Special thanks go to Patrick O'Brien, Paul Gootenberg and Jeff Williamson for their extensive critiques. The authors also benefited from a research grant of the College of New Jersey and would like to thank Rohan Padhye for excellent research assistance. Alejandra Irigoin would like to acknowledge support from an Andrew W. Mellon Fellowship at the John Carter Brown Library. Regina Grafe has been able to undertake this research thanks to a Prize Fellowship from Nuffield College, Oxford.

${ }^{1}$ This literature is now very well developed but goes back to Douglas C. North and Barry R. Weingast, "Constitutions and Commitment: The Evolution of Institutions Governing Public Choice in Seventeenth-Century England," Journal of Economic History XLIX (1989). and Brad De Long and Andrei Shleifer, "Princes or Merchants.
} 
conditions created by climate, topography, flora, fauna and soil conditioned growth through the relation between humans and nature and the disease environment. ${ }^{2}$ Many authors, however, do not intend to simply substitute factor endowments for institutions as the fundamental source of differential growth. Instead they argue that geography mattered but only through its impact on institutions. This is a line of argument most recently pursued by Daron Acemoglu, James Robinson and co-authors, as well as William Easterly and W. Levine and Dani Rodrik et al. $^{3}$ In the context of the divergence between North and South America it is most closely associated with the names of Stan Engerman and Ken Sokoloff. ${ }^{4}$ However, the lines between an explanation largely based on the exogenous variable geography and one based on endogenous institutions shaped by geography are often blurred. The argument tends to become either geographically determinist, as in the case of Acemoglu et al. (2001), or underspecified in terms of causes and consequences as in Gallup et al. (2003) who retreat into the tautological position that "the connection between geography and development is ultimately driven by

European City Growth before the Industrial Revolution," Journal of Law and Economics 36 (1983).

${ }^{2}$ See e.g. J Diamond, Guns, Germs and Steel (New York, 1997)., J.L. Gallup, Jeffrey D. Sachs, and A.D. Mellinger, "Geography and Economic Development," NBER working paper 6849 (1998)., and Jeffrey D. Sachs, "Institutions Don't Rule: Direct Effect of Geography on Per Capita Income," NBER working paper 9490 (2003).

${ }^{3}$ Daron Acemoglu, Simon Johnson, and James Robinson, "The colonial origins of comparative development: An empirical investigation," American Economic Review 91 (2001)., Daron Acemoglu, Simon Johnson, and James Robinson, "Reversal of Fortune: Geography and Institutions in the Making of the Modern World Income Distribution," Quarterly Journal of Economics (2002)., William Easterly and W. Levine, "Tropics, Germs, and Crops: How Endowments Influence Economic Development," Journal of Monetary Economics 50 (2003). and Dani Rodrik, Arvind Subramanian, and Francesco Trebbi, "Institutions Rule: The Primacy of Institutions Over Geography and Integration in Economic Development," Journal of Economic Growth 9 (2004).

${ }^{4} \mathrm{~K}$. Sokoloff and S. Engerman, "Institutions, Factor Endowments and Paths of Development in the New World," Journal of Economic Perspectives 14 (2000)., S. Engerman and K. Sokoloff, "The Evolution of Suffrage Institutions in the New World," NBER working paper (2001). and S. Engerman and K. Sokoloff, "Institutional and NonInstitutional Explanations of Economic Differences," NBER working paper (2003). 
unobserved institutional factors that, for historical and other reasons, are correlated with geographical conditions." ${ }^{5}$

Our paper challenges the theoretical premises and historical evidence behind both the NIE and the factor endowment views and offers a historicized, statistically and economically validated explanation for the institutional development and economic growth of Spanish America. Section 1 mobilizes modern historical evidence to severely qualify the conclusions flowing from the original new institutional assumptions about the nature of Spanish rule in Latin America. Section 2, while lending some support to suggestions derived from the theory of factor endowments, revises several distorted assessments of the Spanish empire's political economy that are still taken as the basis for this literature. Our own hypothesis, elaborated in section 2 and furthered in section 3 , highlights the role of history and contingency in presenting a course of events that is missing from the largely a priori and theoretical explanations offered by the factor endowments model and the underspecified and historically uninformed accounts offered by new institutional economics.

\section{The institutional explanation}

It is now fashionable among North American economists and economic historians to see the history of Spain - and that of her empire through the lenses of the history of Britain and the British Empire. Both mother countries emerged out of a late medieval phase of European state formation. As metropolises to the two largest Western empires they

\footnotetext{
${ }^{5}$ See Rodrik, Subramanian, and Trebbi, "Institutions Rule," pp.156ff., for a critique of Acemoglu et al., who interpret their own instrumental variable for disease environment (settler mortality) in such a way that it de facto becomes a geographically determinist theory of institutions. A similar critique has been levelled again Easterly and Levine. See also John Luke Gallup, Alejandro Gaviria, and Eduardo Lora, Is Geography Destiny? Lessons from Latin America (Stanford, 2003).
} 
determined the development of far-flung outposts overseas. ${ }^{6}$ Both empires are credited with, or blamed for, institutional, political and social legacies that characterised the state building and formation of institutions in the new nations that emerged out of the empires in the late $18^{\text {th }}$ and early $19^{\text {th }}$ centuries. The economic and institutional paths that both empires followed could not be more different and these contrasts have become foundational for the construction of meta-narratives of the development of the Atlantic world since the $16^{\text {th }}$ century. Spain is represented as absolutist, interventionist, centralist, statist, bureaucratic, constitutionally disinclined to grant its subjects much local government while extracting revenues from them. England/Britain by contrast is depicted as enjoying parliamentary government, which treated colonies with benign neglect, granting them self-government and rarely interfering in their internal affairs. In theory these constitutional forms seem to explain the very different economic performance of the successors of these colonies: the modern US and the Latin American republics that emerged between 1783 and 1825 .

Among economic historians the view that Spanish Absolutism hindered successful political, social and economic development in Latin America in the long run is very much alive. In an early article, contemporary to "Constitutions and Commitment", North laid out the basis for comparative studies of Spanish and English colonies. He described "a centralized monarchy in Castile [...] that defined the institutional evolution of both Spain and Latin America". In his view, Spain relied on the extraction of state revenues from outside sources, be it from Naples, the Low Countries or the New World and control over these revenues "entailed a large and elaborate hierarchy of bureaucrats armed with an

\footnotetext{
${ }^{6}$ In territorial terms the Spanish Empire since the $16^{\text {th }}$ century and the British since the $18^{\text {th }}$ century were a category apart from their Portuguese, Dutch and French competitors.
} 
immense outpouring of royal edicts [...] designed to provide minute regulation of the economy." ${ }^{7}$ North also blamed the uniformity imposed by Spanish religion, governance and administration for Latin America's poor performance, which he contrasted with an English regime that supposedly allowed for diversity in the local political structure of its American colonies only mildly regulated through the Navigation Acts. ${ }^{8}$ All this allegedly flowed from Parliament's triumph over the monarchy in 1688, which constrained the crown constitutionally and created the legal and administrative environment in which the interests of commercial elites and the crown were aligned to generate long-run growth. ${ }^{9}$

Historians of Spain and its Empire would disagree more or less strongly with these Anglo-Saxon views. They have read the historiography that shows that the absolutist painting of both Spain and its possessions overseas is a caricature and would presumably agree more readily with Halperín Donghi's assessment that even in its European core "Absolutism was an aspiration rather than an effective political regime". ${ }^{10}$

\footnotetext{
${ }^{7}$ Douglass C. North, "Institutions and Economic Growth: An Historical Introduction," World Development 17 (1989).

${ }^{8}$ Ibid., p.1329.

${ }^{9}$ North and Weingast, "Constitutions and Commitment." Compare this with the eminent historian of Spain John Elliott, who warned historians that "parliaments could be just as arbitrary and intrusive as kings". See J.H. Elliott, "Empire and state in British and Spanish America," in Le Nouveau Monde. Mondes Nouveaux. L'experience américaine, ed. Serge Gruzinski and Nathan Wachtel (Paris, 1996).

${ }^{10}$ Tulio Halperín Donghi, "Backward Looks and Forward Glimpses from a Quincentennial Vantage Point," Journal of Latin American Studies Supplement (1992): p. 221. The author goes on to explain that in Spanish America "Intransigence on matters of principle had to be even more tempered by accommodation with reality." See also for Spain H. Nader, Liberty in Absolutist Spain. The Habsburg Sale of Towns, 1516-1700 (Baltimore and London, 1990).; Charles J. Jago, "Habsburg Absolutism and the Cortes of Castile," American Historical Review 86 (1981).; I.A.A. Thompson, "Absolutism in Castile," in Absolutism in Seventeenth-Century Europe, ed. J. Miller (Basingstoke, 1990).; I.A.A. Thompson, "The End of the Cortes of Castile," Parliaments, States and Representation 4 (1994).; R. MacKay, The Limits of Royal Authority. Resistance and Obedience in Seventeenth Century Castile (Cambridge, 1999). and Jean O. Maclachlan, Trade and Peace with Old Spain (New York, 1974).; for Latin America Elliott, "Empire and state in British and Spanish America.", John Lynch, The Colonial Roots of Latin American Independence, Latin America between
} 
Yet, economic historian's lack of attention to these modern interpretations of the histories of Spain and its empire has contributed to the diffusion of an Anglo-Saxon paradigm of state and empire building. The model moreover transcended change over time to mature into a Whiggish historiography for a Washington consensus on optimal political, economic and cultural development for our own time.

The real nature of Spain's political and social compact can be exposed when looking at the way in which political actors, crown, Cortes (Parliament), cities, towns, nobility, humble subjects and church bargained over how to finance the state and its military needs. The modes and location of such negotiations, legal challenges in the courts, debate in the king's councils and in the Cortes, or unruly riots in the main square reveal much about where authority was located in this society. Historians have illuminated many aspects of a 'Spanish path to absolutism' through their studies of how decisions over fiscal exactions were made. Elsewhere we have complemented this with another angle of research that has received less attention: An analysis of the outcome of these negotiations in terms of the relative tax incidence born by the different fiscal districts within Spain and the Spanish American possessions offers many insights into the nature of Spanish rule that greatly differs from stylised interpretations in the new-institutionalist textbook. ${ }^{11}$

These textbook interpretations of the divergent economic paths of European colonies in North and South America over time are tightly

Colony and Nation (London, 2001)., and James Lockhart and Stuart Schwartz, Early Latin America. A history of colonial Spanish America and Brazil (Cambridge, 1983). ${ }^{11}$ Maria Alejandra Irigoin and Regina Grafe, "Bargaining for Absolutism. A Spanish Path to Empire and Nation Building," University of Oxford. Discussion Papers in Economic and Social History (forthcoming). Our comparison of the political economic aspects of Spanish rule in the peninsula with the Spanish American possessions reveals that in spite of all the idiosyncrasies of Spanish rule in America differences both between Spanish European and American possessions - and throughout time - can be easily overdrawn. 
focused on the legacy of colonial institutions for the post-independence period. ${ }^{12}$ They draw upon a traditional political history of a continent marred by political divisions, endemic civil wars, despotic rule and serious levels of disorder, which restrained the potential for growth possessed by most national economies. In short, the new institutional explanation for Latin American economic backwardness is anchored in the political disorder and instability that occurred in the postcolonial period but which was rooted in the failures of colonial institutions. Post-Independence disorder in turn did not provide the right conditions for economic growth. This quotation captures a general view.

“.. Widespread political instability and violence distinguish much of Latin America. While the US enjoyed an enduring set of political arrangements that both provided stability and protected markets from predation, most of Spanish America erupted in internecine war. Instability diverted resources from economic activity and channelled them into caudillo armies and a variety of praetorian efforts. Instability made it impossible to establish institutions that could bring the expected private returns rate from investment closer in line with social returns." ${ }^{13}$

North, Weingast and Summerhill certainly recognise that "The Spanish Crown had long provided an important enforcement mechanism" and that without it political instability followed, which in turn increased uncertainty and raised transaction costs. But this kind of statement raises more problems than it solves. For example, two obvious questions arise:

\footnotetext{
${ }^{12}$ See Ibid.; J. Coatsworth, "Economic and Institutional Trajectories in Latin America," in Latin America and the World Economy since 1800, ed. J. Coatsworth and A.M. Taylor (Cambridge/MA, 1998).; Douglass C. North, Barry R. Weingast, and W. Summerhill, "Order, Disorder and Economic Change. Latin America verus North America," in Governing for Prosperity, ed. B. Bueno de Mesquita and H.L. Root (New Haven, 2000).; J. Coatsworth and Jeffrey G Williamson, "Always protectionist? Latin American tariffs from Independence to Great Depression," Journal of Latin American Studies 36 (2004).; Stephen Haber, "Introduction," in Political Institutions and Economic Growth in Latin America: Essays in policy, history and political economy, ed. Stephen Haber (Stanford, 2000).

${ }^{13}$ North, Weingast, and Summerhill, "Order," p.41ff.
} 
What exactly was the post-independence political strife about? And how was it linked to the disintegration of the imperial state, which led not only to political fragmentation, but also to the collapse of a fiscal and monetary regime that had underpinned economic activity in Spanish America for three centuries?

\section{The Spanish American institutional set up.}

Historians of the Spanish Empire claim that the fiscal system set up in colonial Spanish America was more 'modern' than the metropolitan system. They argue e.g. that as opposed to the situation in the Peninsula tax districts were typically not overlapping, institutional hierarchies centred clearly on a principal treasury office in each Audiencia, and there was less tax farming. ${ }^{14}$ Yet, when setting up a fiscal system in the New World Spanish officials took cognizance of an eclectic mixture of institutional precedents from various parts of the Hispanic monarchy. They had no grand new designs. The system was obviously less conditioned by historical exemptions than European fiscal systems but that did not automatically create a more modern fiscal system, i.e. one that was more rational (in a bureaucratic sense), centralised and based upon clear universal rules as to who had to pay what, where and when. ${ }^{15}$ In practice the imperial fiscal system differed from Spain's or Castile's primarily in one significant respect: Thanks to the labour and silver 'discovered' and mined in America the fiscal base expanded rather than contracted.

\footnotetext{
${ }^{14}$ Herbert S Klein, The American Finances of the Spanish Empire. Royal Income and Expenditures in Colonial Mexico, Peru, and Bolivia, 1680-1809 (Albuquerque, 1998). pp.2ff. Elsewhere, however, the same authors indicate that Spanish monarchs used "institutions and officials which had consolidated royal power in Spain during the Reconquest". John TePaske and Herbert Klein, The Royal Treasuries of the Spanish American Empire, vol. 3 Chile and the Rio de la Plata (1982). Vol 1. Introduction.
} 
Otherwise there was no single fiscal authority assessing and collecting a set of uniform and universally applied taxes in Spanish America. Instead the system consisted of a network of quasi autonomous interdependent fiscal districts and authorities. At the main administrative centres and ports treasuries collected revenues and monitored the accounts of sub-cajas. In Peru, e.g. Lima acted as the caja general, Trujillo, Huamanga, Cuzco and Arequipa functioned as cajas principales and Arica and Pasco as subordinate cajas. After the creation of the Viceroyalty of the River Plate, Buenos Aires performed as the top treasury. Thereafter Potosi, Arequipa, Quito or Santiago became intermediaries in the complex machinery for revenue collection across the empire. Formally, fiscal surpluses were sent from the local cajas to main treasuries but the accounts of individual treasury districts (discussed below) show the administration of the tax collection in the empire was not centralised. Instead each main caja (treasury district) came under the Real Hacienda (the Royal Treasury) or reported to the Contaduria Mayor del Consejo de Indias (Treasury Office of the Indias Council). Fiscal administration changed and evolved over time. The cajas were created and closed according to the income they were placed to yield. In the case of New Spain and the River Plate, local treasury networks seemed to be more organically related to Mexico City and Buenos Aires and most of the cajas in these two viceroyalties were not established before the third quarter of the $18^{\text {th }}$ century. A hierarchy of cajas and their integration in a vice regal network is much less clear in the case of Peru and Upper Peru, where most of the local treasuries had been created in the $16^{\text {th }}$ and $17^{\text {th }}$ century, and where some had been closed by the 1780 s. $^{16}$

\footnotetext{
${ }^{15}$ This appears to be the meaning of 'modern' Klein and TePaske have in mind. Klein, The American Finances. p.2.

${ }^{16}$ See appendix for details about the creation and abolition of cajas. Slicher van Bath tried to identify the networks of cajas by looking at correlation coefficients between their revenues. While he found clear evidence that they were linked, his results also show
} 
No single authority was responsible for the collection, assessment and management of revenues in Spanish America. Taxes were normally levied by royal officials but the church also collected some revenues for the Crown and vice-versa reflecting the links between ecclesiastical and temporal authority under the Spanish monarchy. ${ }^{17}$ Although the rules distinguished between church and state revenues, several similar imposts being collected either by the church or the state blurred distinctions for liabilities. Several officials assigned with specific tasks within each caja shared responsibilities for gathering and spending royal revenues but the relation between them was often one of mutual distrust, conflicting standards and overlapping functions. ${ }^{18}$ Officials were subjected to periodic inspections by the auditing bureau in the colony or by specially appointed investigators. ${ }^{19}$ The mission of the central authorities was, as elsewhere, to eliminate regional differences and to standardise practices throughout the empire. But the centralisation of authority was more of an aspiration than a reality. ${ }^{20}$

While nominally each caja and its officials reported to the Contaduria Mayor of the Council of the Indies and although the bureaucracy looks sophisticated the extensive nature of local governance, time lags in reporting and the existence of several intermediate levels for assessment and collection meant that the Crown rarely had an accurate idea of how much revenue had been collected and

that the system had multiple and shifting centres rather than a clear and persistent hierarchical structure. B.H. Slicher van Bath, Real Hacienda y economía en Hispanoamérica, 1541-1820 (Amsterdam, 1989). pp.39ff.

${ }^{17}$ Under the real patronato de las Indias the king, as patron of the Church of the Indies, acted as the Pope's vicar in ecclesiastical administration, so that royal agents administered ecclesiastical taxes and nominated church dignitaries. John Leddy Phelan, "Authority and Flexibility in the Spanish Imperial Bureaucracy," (1967): $52 .$. 18 Ibid.: pp.53-55. See also Irigoin and Grafe, "Bargaining for Absolutism.".

${ }^{19}$ In 1605 Philip III created the first Tribunales de Cuentas in Lima, Bogota and Mexico, a supervisory and auditing agency, which oversaw the work of the royal treasury officials. TePaske and Klein, Royal Treasuries 3. vol2, fn4.

${ }^{20}$ Phelan, "Authority," pp.51,55.. 
spent. Repeated reports, visits of envoys from Madrid and the reiteration of royal orders can be taken as a measure of the system's inefficiency. Yet, John Elliott has argued that "the extraction of revenues from silver rich societies demanded a strong state structure in order to mobilise their extractive resources. [...] and the deployment of an army of administrative, judicial and financial officials, whose activities (the Crown) carefully monitored."21 Klein also insists that "the remittances of bullion from the Indies demanded close royal control over the workings of the transatlantic trading system."22

Nevertheless, throughout the colonial period outlays by the crown for colonial administration were low. ${ }^{23}$ Total sums spent on salaries represented just three per cent of the total revenues of New Spain; twelve per cent in $16^{\text {th }}$ Century New Granada, and the same in Peru throughout the period. Only in Charcas, in Upper Peru, did expenditures on administration reach 40 percent but "started to converge with Peru and Mexico in the last third of the 18th century". ${ }^{24}$ Charcas was an administrative centre of a large region, the site of the Audiencia and several major public institutions like a university, which explains its large administrative expenditure. Klein speculates that the low ratios in practically all the other districts reflect the relative efficiency of the centralising administration. But there is preciously little evidence on the local or regional level for high degrees of efficiency and/or effectiveness.

\footnotetext{
${ }^{21}$ Elliott, "Empire and state in British and Spanish America," pp.368-69.

${ }^{22}$ Klein, The American Finances. p.5.

${ }^{23}$ We would like to thank Paul Hoffman for making us aware of this. The only places where the Crown invested money were the 'frontier' areas. "Subsidies came in from branches of government based in more central areas, channelled to individuals on the scene through the frontier institutions, so that the latter were able to play on a small scale the usual role of cites as market of goods and labour." Lockhart and Schwartz, Early Latin America. p.289.

${ }^{24}$ Klein, The American Finances., for Peru p. 47, New Spain p. 95, Charcas p. 23. For New Granada in the $16^{\text {th }}$ Century, own estimates from Hermes Tovar Pinzon, El imperio y sus colonias. Las cajas reales de la Nueva Granada en el siglo XVI (Bogota, 1999).
} 
Nor would it appear that generalised coercion explains the low cost of administration. Instead the answer seems to lie in a development that had peninsular Spanish precedents, namely the 'outsourcing' of important fiscal functions to private individuals whose receipts never really figured in the public accounts. ${ }^{25}$ The empire suppressed resistance and exerted control thanks to a particular arrangement of negotiation with its own officials and subjects, the co-optation of its extended bureaucracy and the increasing privatisation of the management of the royal funds by private individuals. ${ }^{26}$ This was effective in order to keep the status quo but not very efficient and ran certainly against any centralising tendency. ${ }^{27}$

Uniformity of the tax system should imply a single fiscal constituency, guaranteeing that there were no systematic differences in the subject's treatment as a tax payer and we would assume in such a system that the tax rates applicable in individual territories and for different activities were at least similar. But there was no single fiscal constituency in Spanish America as the subjects were divided into the república de indios (indigenous population) and the república de españoles (Europeans). The co-existence of two distinct 'commonwealths' within a single geographical area created overlapping jurisdictions. There were early fiscal privileges for indigenous communities as Indian labour was a privilege granted to conquistadores and first encomenderos. Effectively indigenous communities traded tribute for ownership guarantees of their communal lands. For long periods of time Indian traders were exempted from paying the important sales tax, the alcabala. Equally, the Catholic Church remained a separate

25 See Lockhart and Schwartz, Early Latin America. p.106.

${ }^{26}$ John Lynch, "The Institutional Framework of Colonial Spanish America," Journal of Latin American Studies 24 (1992): p.81. and Elliott, "Empire and state in British and Spanish America.". The low spending on administration also meant that the Crown had to rely on agents willing to serve overseas because of the "additional advantages available by using the [Crown's] powers for their own benefits". Halperín Donghi, "Backward Looks," p.223. 
but interdependent fiscal domain. Colonials were not equal before the Hacienda.

The alcabala also illustrates that there was no uniform tax rate. ${ }^{28}$ Even after the alcabala was extended to the indigenous population there were still different rates in different regions, and for different products: in the late 18th century they ranged from four percent in Buenos Aires, six percent in both Perus to eight percent in Mexico (lowered to six in 1790). The effective burden has been estimated as four to seven percent in Peru and around one and a half to two and a half in Upper Peru in the late eighteenth century. ${ }^{29}$ There were also different concepts for the alcabalas (viento, mar, de Castilla, cabezón) applicable in the same territory. These were taxes on goods varying according their origin or charged differently upon exchanges, whether realised overland or by sea. In 1776 the alcabala was extended to staple foodstuffs (chuño, charqui, ají, aguardiente), as well as to tobacco, sugar and native textiles in Peru. However, when in subsequent years the Crown tried to charge the tax on grain and maize, Indians in Upper Peru revolted; when the Crown suggested a higher rate for the same tax in New Granada or to change the mode of collection the reaction was similar. The history of tax revolts in Spanish America suggests strongly that the meaning of what was called alcabala in terms of the tax base and incidence depended strongly

\footnotetext{
${ }^{27}$ Irigoin and Grafe, "Bargaining for Absolutism.".

${ }^{28}$ See Carlos Newland, "La presión fiscal en el espacio peruano, 1691-1790," mimeo Buenos Aires (2002). and Maria Alejandra Irigoin, "Macroeconomic aspects of Spanish American Independence. The effects of fiscal and monetary fragmentation, 1800s1860s," Universidad Carlos III, Depto de Historia Económica working paper (2003). ${ }^{29}$ In late colonial times alcabalas yielded 14 percent of total revenues in Peru, 24 in percent Chile and six percent in the Upper Peru. Already in 1780 alcabalas rendered more than silver taxes to the Mexican Treasury. Carlos Marichal, La bancarrota del virreinato: Nueva Espana y la las finanzas del imperio espanol 1780-1810 (Mexico, 1999).
} 
on the outcome of local negotiations between crown and American subjects. ${ }^{30}$

The above discussion contrasts sharply with the notion of a relatively modern fiscal administration at the service of a predatory, absolutist, all-powerful Spanish state that the institutionalist approach has painted. The crown had no means to impose a uniform tax system on its subjects in the colonies or at home. Instead the patchwork reality of fiscality in the colonies illustrates that Spanish imperial rule was to a surprising degree the result of negotiations between the crown, its own bureaucracy and different economic interests in the colonies.

\section{The factor endowments explanation}

Engerman and Sokoloff deployed a factor endowment model to challenge and qualify the emphasis accorded to institutions for explanations of differential paths of developments in the Americas. Their argument raised the basic question: where do the differences in institutions come from? They shifted the focus to the distinct resource environments in which British and Spaniards settled in the New World after 1500 and claimed that access to resources led to very different degrees of inequality persisted over time and affected the course of development through their impact on the institutions that evolved. ${ }^{31}$ The

\footnotetext{
${ }^{30}$ Allen J. Kuethe, Military Reform and Society in New Granada, 1773-1808 (Gainesville, 1978), Scarlett O'Phelan Godoy, "Las reformas fiscales borbonicas y su impacto en la sociedad colonial del bajo y alto Peru," in The economies of Mexico and Peru during the late colonial period, 1760-1810, ed. N Jacobsen and H.J. Pule (Berlin, 1996)., Scarlett O'Phelan Godoy, Un siglo de rebeliones anticoloniales. Peru y Bolivia 1700-83 (Cuzco, 1988). and Rebecca Earle Mond, "Indian Rebellion and Bourbon Reform in Granada. Riots in Pasto 1780-1800," Hispanic American Historical Review 73 (1993).

${ }^{31}$ Engerman and Sokoloff, "Institutional and Non-Institutional Explanations.", p.18ff , also Sokoloff and Engerman, "Institutions."; Engerman and Sokoloff, "Evolution." and Stanley L. Engerman and Kenneth L. Sokoloff, "Colonialism, Inequality, and Long-Run Path of Development," NBER working paper 11057 (2005).
} 
extractive nature of the European empires, the forced transportation of African slaves (to use here "migration" is a euphemism), disparities in human capital and the relative success of colonial elites at securing - and extending - local political power emanated from differences in resources.

Since the inception of this analytical stream it was criticised for the implicitly path dependent nature of the argument, which in later versions evolved into an even more ambiguous response to the "sins" of an original institutional set-up as the bedrock of all differences. The revised argument held that the availability of extractive resources, whether silver, land or labour, installed a very unequal access to wealth and political leverage that subsequently crystallised in the Spanish part of the Americas. By contrast, much less favoured colonies in North America - at least in terms of valuable resources at the time of the "discovery" and conquest $16^{\text {th }}$ century - engendered a more equal distribution. The larger political leverage of the elites in Spanish America was the source of the great wealth inequality that Latin America features today. This contributed to the evolution of institutions, which protracted the original inequalities in former Spanish colonies, and hence prevented the occurrence of faster, intensive and sustained growth thereafter. Thus, Spanish colonial institutions protected "the privileges of the elites and restricted opportunities for the broad mass of the population to participate fully - like in the post revolutionary US - in the commercial economy even after the abolition of slavery". ${ }^{32}$

There are several problems with this argument. For one thing, it is not clear how to characterise let alone measure the initial distributions of wealth, income and power if not by some institutional or technological (warfare) differences at the time of the "conquest". This of course moves the argument closer to an institutionalist position than Engerman/Sokoloff would like. We are, however, more interested in the role ascribed to factor 
endowments as foundational for the evolution of institutions. Rights to land and labour, or to exploit mineral resources available in particular colonies are at the root of the initial conditions within and across colonies. "The initial conditions had lingering effects, not only because certain fundamental characteristics of New World economies were difficult to change, but also because government policies and other institutions tended to reproduce them". ${ }^{33}$ Inequalities tended to reproduce themselves in South America. Conversely, North American factor endowments promoted greater equality and a more favourable institutional set up. For example, Engerman and Sokoloff maintain that suffrage was granted and extended earlier in North than in Spanish America where access to land ownership and public education were also unfavourable. ${ }^{34}$

However, the argument is controversial. Political historians point out that Spanish American republics relied at least constitutionally on a much wider franchise (for men) than their contemporaries elsewhere abolishing the legal distinctions between indigenous people and whites and emancipating slaves beginning in $1813 .{ }^{35}$ In fact, Spanish America enjoyed almost universal suffrage very early on. The main difference from the US was that in Spanish America the active right to vote, i.e. the right to be elected, was often more restricted than the right to elect and that the turnout in elections remained much lower. ${ }^{36}$

\footnotetext{
${ }^{32}$ Sokoloff and Engerman, "Institutions," p221.

33 Ibid.: p.223.

${ }^{34}$ Ibid.: p.228.

${ }^{35}$ There is still a tendency in the literature to paint over the fact that Native and African Americans only achieved full political and civil rights in the US in the 1974 and 1962 respectively.

${ }^{36}$ Francois-Xavier Guerra, "The Spanish American Tradition of Representation and Its European Roots," Journal of Latin American Studies 26 (1994): p.9 and 13. Sokoloff and Engerman also entirely omit the male universal right to vote granted by electoral laws in the River Plate. Since 1821 polls took place regularly, even if electoral turnout was low. See M. Ternavasio, La revolución del voto. Política y elecciones en Buenos Aires, 1810-1852 (Buenos Aires, 2002). Engerman and Sokoloff's other indicators, namely public investment in schooling and concentration of land ownership, are no less problematic, since it is entirely unclear if they were the cause of poor economic
} 
Other authors, too, have highlighted what they saw as the extractive nature of the colonial bound and its detrimental effects on equality or on the institutional design. Acemoglu et al have produced a series of essays in which they compare the colonial origins of different present day economies. Though they insist that the persistence of colonial institutional differences is the root cause of subsequent differential development, they also argue that (non)-feasibility of settlement in some regions due to very high mortality rates was the main reason why extractive institutions were created in the first place. ${ }^{37}$ But, like Engerman and Sokoloff, they support their clear theory rather poorly with an outdated historical depiction of what the Spanish empire was in terms of institutions and exploitation of the available resources, land, labour or metal ores. Paradoxically, institutionalists and factor endowment advocates share the assumption that some pre-existing ad hoc factor (institutional or geographical) created an unequal distribution either of resources or of power and therefore of income, or rents. This, in turn, established different institutions, which made it impossible for the postcolonial states in Latin America to follow theoretically expected paths towards growth and industrialization. ${ }^{38}$

The emphasis on resource endowments has provided an important corrective to the institutionalist approach by stressing how differences in terms of population densities and raw materials shaped institutional responses in the Americas. Nevertheless this view accepts exactly the same crude specification of the institutional set-up of Spanish colonialism. Just as the absolutist caricature of North et al. was far from the facts of

performance or the consequence of failing macroeconomic situations or recurrent fiscal crisis. See Irigoin, "Macroeconomic aspects.".

${ }^{37}$ Acemoglu, Johnson, and Robinson, "The colonial origins.".

${ }^{38}$ This is the case of North and Weingast, "Constitutions and Commitment." or Acemoglu, Johnson, and Robinson, "Reversal of Fortune."; Acemoglu, Johnson, and Robinson, "The colonial origins."; Daron Acemoglu, Simon Johnson, and James 
Spanish rule in the Americas, here too relations between resource endowments and growth were shaped in more complex ways than Engerman/Sokoloff or Acemoglu et al. have allowed.

Resources and revenues in the finances of Spain's Empire in America.

At this stage of the discourse dichotomizing geography and institutions we need to understand the nature and scope of Spanish colonial rule. The clearest way to comprehend that is to explore inferences obtained from fiscal data available from the accounts of colonial treasury districts in today's Mexico, Ecuador, Peru, Chile, Bolivia, Argentina, Uruguay and Paraguay collected by Herbert Klein and John TePaske, with which we have created two five-year samples. ${ }^{39}$ No data are available for the Caribbean, Central America and part of New Granada (Venezuela and Columbia) but tables 1 and 2 display the basic outlines of the colonial fiscal system. The total revenue raised in districts for which we have data amounts to about 255 million pesos for the years 1785-89. Ten years later royal revenue had increased to almost 420 million pesos in five years and most of it emanated from the Viceroyalty of New Spain (Mexico). The US can serve as a useful point of comparison for the impressive magnitude of Spanish colonial revenues, if we take into account that its population, about 5.3 Mio people in 1800, was very close to that of New Spain. Total US revenue for the period 1796-1800 was $\$ 43,363,000$ compared to $338,000,000$ pesos for New Spain. ${ }^{40}$ Even if we

Robinson, "Institutional Causes, Macroeconomic Symptoms: volatility, crises and growth," NBER working paper (2002).

${ }^{39}$ For a description of the data set see Appendix 1.

${ }^{40}$ For US population figures see US Bureau of the Census, Historical Statistics of the US, Old Series, Series B (Washington, 1960). Area and Population Continental, US 1790-1940, p.25. For fiscal receipts US Bureau of the Census, Historical Statistics of the US. Colonial Times to 1957, Series Y (Washington). Federal Government Receipts 
assume that the fiscal burden in New Spain was considerably higher, an eightfold difference necessarily implies that per capita GDP in the domestic economy of New Spain was very high. And even backward Chile raised four times more revenue in the late 1790s than the most populous state of the US, Pennsylvania. ${ }^{41}$

Spain certainly benefited from private remittances from the colonies, as well as taxes levied in the metropolis on trade between the colonies and the Peninsula. ${ }^{42}$ But direct transfers to the motherland of fiscal receipts levied in the colonies look modest compared to intracolonial transfers, i.e. payments flowing between treasury districts within Spanish America (and the Philippines). Column 4 of tables 1 and 2 illustrate the degree to which Spanish colonial rule shifted financial resources around different regions in the Empire. The values represent the balance of incoming and outgoing intra-colonial transfers for each macro administrative region. Up to 45 percent of the revenue raised in colonial Spanish cajas in the late $18^{\text {th }}$ century was not spent in the same district. Thus, our tables illustrate three basic features of Spanish imperialism. Firstly, it shows its global significance as a source of bullion for the world economy; revenues in 1785-89 alone were nearly equal to the total silver imports through Canton from 1719 to $1833 .{ }^{43}$ The value of English East India imports from China in 1796-1800 was 23 million pesos.

and Administrative Budget 1789-1939, p.352-57. Note that the dollar and the peso were practically at parity.

${ }^{41}$ The total revenue of Pennsylvania amounted to $\$ 250,969$ and 11 cents in 1802 . See Samuel Hazard, ed., The Register of Pennsylvania. Devoted to the Preservation of Facts and Documents, and every other kind of useful information respecting the State of Pennsylvania, vol. 1 (Philadelphia, January to July 1828).

${ }^{42}$ In the late $18^{\text {th }}$ century the total contribution of revenue that the Spanish Hacienda derived from the Americas, including direct contributions, monopolies and trade taxes, was about 20 percent. Jacques A. Barbier and Herbert S. Klein, "Revolutionary Wars and Public Finances: The Madrid Treasury, 1784-1807," Journal of Economic History 41 (1981): p.328.

${ }^{43}$ Maria Alejandra Irigoin, "Bringing the New World Back into Global History (The origins of another great divergence?) Spanish American silver bound for China on 
Secondly, the figures illustrate Spanish imperialism's re-distributive features of which fiscal remittances to the metropolis by the end of the $18^{\text {th }}$ century were only a small proportion. Re-distribution within the colonies was far larger. As TePaske has pointed out, the retention rate of royal revenue within the colonies began to increase very early on. In the 1590s about 64 percent of the revenue collected by Lima was transhipped to Spain but after the 1660s even here they never exceeded ten percent. The picture for Mexico was comparable. ${ }^{44}$ Thirdly, transfers between regional districts seem to have been crucial for the governance of the Empire and this feature of Spanish colonialism contrasted strongly with the fiscal system operating in the New England colonies.

North American vessels 1780s-1820s," paper presented at DRCLAS Latin America History Workshop, Harvard (2005)..

${ }^{44}$ John J. TePaske, "New World Silver, Castile, and the Philippines, 1590-1800," in In Precious Metals in the Later Medieval and Early Modern Worlds, ed. John F. Richards (Durham, NC, 1983), pp.428ff.. Unfortunately, we do not know what the Lima figures meant relative to the overall revenue collected in Peru, but they must have been the upper bound. They fell to 45 percent in 1600,30 percent in the 1630 s and after shortly rising again to 46 percent during Olivares' reforms it plummeted between 1660 from 12 percent to 1 percent in the 1680s and did not rise over 10 percent (of a reduced total revenue) thereafter. The fall in actual revenues after between the 1690 s and 1760 s led to "diminishing the volume of pesos shipped to the metropolis to miniscule amounts". At the same time more money went to the garrisons Concepción, Chiloe and Valdivia, Panama, Callao and Guayaquil and to finance the war with Araucanos in Chile. In Mexico between 1590 and 1640 roughly half of all crown revenue was remitted either to Castile or the Philippines, though we do not know how much of this went to either place, i.e. how much was intra-colonial. Up to 1680 the total went down to one third flowed out, in the decades 1690-1700 less than one quarter. Unlike Peru, however, the reduced flow of Mexican bullion to Castilian coffers could not be attributed to a decline in mining production. 
Table 1 Revenues and remittances to Spain and Net Intra-colonial transfers between macro-regions 1785-89, (Spanish pesos)

\begin{tabular}{|l|r|l|l|l|c|}
\hline & Revenue & $\begin{array}{l}\text { Transfers } \\
\text { to Spain }\end{array}$ & $\begin{array}{l}\text { Transfers } \\
\text { to Spain } \\
\%\end{array}$ & $\begin{array}{l}\text { Net intra- } \\
\text { colonial } \\
\text { transfers }\end{array}$ & $\begin{array}{l}\text { Net intra- } \\
\text { colonial } \\
\text { transfers } \\
\%\end{array}$ \\
\hline New Spain & $176,854,695$ & $10,558,867$ & 6.0 & $-39,770,020$ & 22.5 \\
\hline Peru & $43,133,235$ & $1,228,049$ & 2.8 & $1,030,538$ & 2.4 \\
\hline Upper Peru & $15,317,565$ & & 0 & $-2,498,928$ & 16.3 \\
\hline Chile & $4,693,050$ & 4,221 & 0.1 & 976,468 & 20.8 \\
\hline $\begin{array}{l}\text { Rio de la } \\
\text { Plata }\end{array}$ & $15,195,900$ & & 0 & $7,070.009$ & 46.5 \\
\hline
\end{tabular}

Table 2 Revenues and remittances to Spain and net intra-colonial transfers between macro-regions 1796-1800, (Spanish pesos)

\begin{tabular}{|l|r|r|r|r|c|}
\hline & Revenue & $\begin{array}{l}\text { Transfers } \\
\text { to Spain }\end{array}$ & $\begin{array}{l}\text { Transfers } \\
\text { to Spain } \\
\%\end{array}$ & $\begin{array}{l}\text { Net intra- } \\
\text { colonial } \\
\text { transfers }\end{array}$ & $\begin{array}{l}\text { Net intra- } \\
\text { colonial } \\
\text { transfers } \\
\%\end{array}$ \\
\hline New Spain & $337,941,470$ & $21,573,595$ & 6.4 & $-43,313,788$ & 12.8 \\
\hline Peru & $29,317,105$ & 12,262 & 0 & $1,060,755$ & 3.6 \\
\hline Upper Peru & $16,295,275$ & & 0 & $-1,432,247$ & 8.8 \\
\hline Chile & $14,293,540$ & 5,945 & 0 & 353,976 & 2.5 \\
\hline $\begin{array}{l}\text { Rio de la } \\
\text { Plata }\end{array}$ & $18,863,575$ & & 0 & $8,008,496$ & 42.5 \\
\hline
\end{tabular}

Note: the sums of net payments will not add up since important regions, especially New Granada, Cuba and the Philippines are missing. Nevertheless, these overview data give a taste of the order of magnitude of net transfers involved.

Intra-colonial transfers in Spanish America have attracted some scholarly attention from local and regional historians but there has been next to no analysis of their role in comparisons of imperial governance despite the fact that this was an exceptional feature of Spanish imperialism. The operation of substantial interregional fiscal transfers within a colonial sphere, which was moreover fiscally self-sufficient merits 
elaboration and far closer analysis than has been accorded in recent interpretations of path dependent institutional and/or endowment based explanations for South American retardation after Independence.

The pattern of re-distribution between the larger regions, New Spain, Upper Peru, Peru, Chile and Rio de la Plata is similar between 1785 and $1800 .{ }^{45}$ Revenues assessed and collected in New Spain flowed via Havana to other colonial regions in the Spanish Caribbean, such as Louisiana, Florida, other smaller Spanish possessions in northern Mexico and California, or they were channelled via the famous Manila Galleon to the Philippines. ${ }^{46}$ Direct data for the Caribbean are few and far between, but we know e.g. that Cartagena de Indias received in our first sample period a total of 2,348,929 pesos in situados and 2,194,629 pesos in the second. ${ }^{47}$ Manila received 1,144,138 pesos between 1791 and 95 and 4,341,623 pesos between 1796-1800. During the following two five year periods these fell to 1.8-1.9 Mio pesos. ${ }^{48}$ The best number for the monies actually received in Cuba as situados is de la Sagra's account of 68,641,605 pesos between 1788 and 1804 of about 4 Mio per

\footnotetext{
${ }^{45}$ Most of these were not separate administrative regions. Charcas and River Plate were part of the same viceroyalty. Similarly Chile and Peru were part of the same political unit. The cajas of Vico Pasco, Quito ad Guayaquil corresponded to the viceroyalty of Granada. They denote the main four geopolitical units that appeared as countries with sovereign states in the post independence.

${ }^{46}$ Carlos Marichal and Matilde Souto Mantecón, "Silver and Situados: New Spain and the Financing of the Spanish Empire in the Caribbean in the Eighteenth Century," Hispanic American Historical Review 74 (1994). Much of this silver ultimately found its way to China. This is not only true for the Manila situado but transfers to the Caribbean also ended up in Canton via the intermediation of North American merchants.

TePaske, "New World Silver."

${ }^{47}$ Adolfo Meisel, "Subsidy-led growth in a fortified town: Cartagena de Indias and the Situado, 1751-1810," paper presented at LACLIO 2000 (2000).

${ }^{48}$ For the 1790 s see TePaske, "New World Silver."; for the first decade of the $19^{\text {th }}$ century A. Jara, "Las Conexiones e Intercambios Americanos con el Oriente bajo el marco Imperial Español," in European Entry into the Pacific. Spain and the Acapulco Manila Galleons, ed. Dennis O. Flynn, Arturo Giráldez, and James Sobrado (Aldershot, 2001), p.235.
} 
year. ${ }^{49}$ Within South America Peru, Chile and above all the Rio de la Plata were net beneficiaries of transfers.

Table 3 Net transfers between Spanish American treasuries 1785-89, Spanish pesos.

Table 4 Net transfers between Spanish American treasuries 1796-1800, Spanish pesos. (See appendix 2)

Behind this less than complete macro-picture there is an even more complex picture disaggregated to the level of 54 individual cajas reported in Tables 3 and 4 in appendix 2. 17 cajas gained from net transfers and for seven these transfers were the main source of revenue in 1785-89. Ten years later (1796-1800) 19 out of 54 treasuries were subsidised and one in four depended on transfers for the largest share of their resources. Only a small number of cajas received and paid out about the same amount or did not transfer or receive any money at all, and these were mostly fiscally unimportant districts. The story is even more complex on a year on year basis. Some districts enjoyed a permanently positive balance of net-transfers, others were constantly sending out more than they received, but a substantial number was net recipient in some years, payer in others.

Maps 1 and 2 illustrate the spatial distribution of net payers (dark grey), net recipients (light grey) and those that had zero net transfers (very light grey) in the later sample for Mexico and the two Perus. ${ }^{50}$ It

\footnotetext{
${ }^{49}$ These are likely to be substantially lower than the ones dispatched from New Spain. They include situados y factoria tobacco. Ramon de la Sagra, Historia económica, política y estadística de la isla de Cuba or sea de sus progresos en la población, la agricultura, el comercio ys las rentas (Habana, 1831).

${ }^{50}$ The actual borders between treasury districts within the same intendencia are not known. Thus borders in the form of clearly identifiable straight lines introduced between
} 
qualifies the motivation most often named as the origin of the transfer system: defence. As historians know coastal areas clearly played a large part in the defence of the empire, but so too did areas bordering hostile neighbours such as the north of Mexico or regions close to Portuguese spheres of influence, like Paraguay. Not all military outposts were on the coast. Nor were all coastal areas military outposts; Lima (and its port Callao) is a case in point. Our maps confirm that military need was only one of several factors behind intra-colonial transfers.

If defence was argued to be the driving principle on the expenditure side of colonial fiscal balance sheets, the exploitation of mining and labour resources was seen as the key feature on the revenue side. This is the core preposition accepted by institutionalists and resource endowment advocates alike: Spanish colonialism was rooted in the collection of rents from the exploitation of silver deposits and indigenous (and to a lesser extent slave) labour either because the predatory structure of the Spanish state created a colonial society based on such rent seeking (the NIE position) or because the available resource endowment simply made it the obvious choice (the factor endowment position). With this in mind the traditional view of the predatory, resource extracting Spanish imperial state can be translated into at least partially testable hypotheses. If the standard notion of intra-colonial transfers as a simple means to fund defence was true we should be able to identify a strong statistical association between large positive transfers and defence spending. Equally, if the extraction of revenues from extractive sectors was a key element of Spanish rule, there should a strong negative correlation between fiscal revenue derived from mining and agriculture and inter-caja transfers, i.e. an outflow of revenue from mining and distribution only and do not pretend to reflect the accurate size of either district. 
agricultural regions. Finally, districts that organised shipments to Spain should exhibit higher intra-colonial transfers.

The data published by TePaske and Klein have allowed us to investigate the sources of revenue and destinations of expenditure for individual cajas for our two sample periods and re-classify them into broad categories. (See appendix 1 for details on the data.). On the revenue side we distinguish between taxes levied upon mining, agriculture, trade/consumption and the church. The guiding principle of our sectoral classification was tax incidence (i.e. which sector of the economy was affected by these particular taxes). Income from monopolies has been assigned to the relevant sectors and we combine taxes on labour and production under the same heading as long as they were borne by the same sector. ${ }^{51}$ We exclude a large number of administrative taxes, e.g. stamped paper (papel sellado) from our analysis, since it is not clear where they fell. ${ }^{52}$ The category church picks up taxes collected by the church but that were the property of the crown and income the state derived from the so-called temporalidades, the confiscation of Jesuit property in the late 1770s. On the debit side of these reconstructed accounts, we have separated out military spending, transfers to Spain and the intra-colonial transfers.

Our purpose is not to analyse the performance of the economy but that of the state. ${ }^{53}$ The data set we created allows us to investigate relationships between particular sources of revenue and patterns of

\footnotetext{
${ }^{51}$ See Appendix 1 for details. For instance we count monopoly revenues from alcohol taxes as trade and consumption; and revenue from the mercury monopoly is classified as mining. Indian tribute (in its origin a labour tax) and the tenth (diezmo) on agricultural production are both subsumed in agriculture.

${ }^{52}$ Even without administrative taxes our categories cover a very high percentage of total income. See Appendix 1 for the share of income actually encompassed by our categories.

${ }^{53}$ We do not claim that the tax burden on individual sectors reflects the composition of the real economy very closely. Several authors have questioned the suitability of fiscal receipts to proxy trends in the economy, which was the main purpose of the initial analysis for which Te Paske and Klein collected this superb database.
} 
expenditure on the one hand, and net intra-colonial transfers on the other and thus find answers to the various hypotheses formulated above. Table 5 reports results of a simple OLS regression model investigating the strength of the relationship for the two sample periods. We report results respectively for each period introducing as independent variables the revenue derived from the four sectors (mining, trade and consumption, agriculture and church), as well as expenditure spent on military expenses. We add a dummy variable for large seaports. The larger seaports of the colonial Spanish America were the points were the silver economy met with international trade. Therefore we wanted to investigate if treasury districts centred on one of the large ports were more or less likely to receive intra colonial transfers.

Table 5 Regression results: dependent variable net transfers

\begin{tabular}{|c|c|c|c|c|c|c|c|c|}
\hline & $\begin{array}{c}1 \\
1785-89\end{array}$ & & $\begin{array}{c}2 \\
1785-89\end{array}$ & & $\begin{array}{c}3 \\
1796-1800\end{array}$ & & $\begin{array}{c}4 \\
1796-1800\end{array}$ & \\
\hline Mining revenue & -0.352 & $\star \star \star ~$ & -0.375 & $\star \star \star *$ & 0.004 & & -0.032 & \\
\hline Trade/Cons. & -0.402 & $\star \star \star \star$ & & & & & & \\
\hline Revenue & & & -0.391 & $\star \star \star *$ & -1.410 & $\star \star \star *$ & -1.369 & 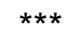 \\
\hline Agriculture & -0.792 & ** & & & & & & \\
\hline revenue & & & -0.867 & $\star *$ & -0.123 & & -0.223 & \\
\hline Church revenue & -0.578 & $\star \star \star *$ & -0.562 & 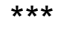 & 0.302 & *** & 0.247 & $\star * *$ \\
\hline Military & 0.409 & $\star \star \star \star ~$ & & & & & & \\
\hline $\begin{array}{l}\text { Expenditure } \\
\text { Remittances to }\end{array}$ & & & 0.425 & $\star \star \star \star ~$ & 0.602 & 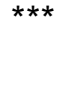 & 1.046 & $\star \star \star \star$ \\
\hline Spain & & & -0.218 & $\star \star \star ~$ & & & -0.273 & $\star \star \star *$ \\
\hline Sea Port & 348242 & $\star \star \star$ & 390792 & $\star \star \star ~$ & 269565 & 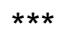 & 151747 & $\star \star$ \\
\hline Constant & -12842 & & -6286 & & -47663 & & -52443 & \\
\hline$N$ & 263 & & 262 & & 273 & & 273 & \\
\hline Adj. R2 & 0.60 & & 0.61 & & 0.82 & & 0.86 & \\
\hline
\end{tabular}

Regression 1 for the period 1785-89 shows that a higher share of revenue derived from mining was strongly associated with lower net transfers, but the coefficient is rather small. In fact, it seems that agricultural districts were much more punished by the system of re- 
distribution of resources, with an additional peso derived from agricultural taxes being associated with 0.8 pesos less in net-transfers, twice the rate of either mining or trade. ${ }^{54}$ Thus to the extent that there was an extractive element to the structure at this point in time, districts that received much of their income from agriculture indeed received lower or negative transfers but mining districts fared well. The modest contribution of mining in our results seems to be in line with Mahoney's research, which equally found that the presence of silver mining in a region did not determine the institutional legacy in significant ways. At the same time, it questions much of the 'factor endowment' literature. ${ }^{55}$

The relatively high negative coefficient for church is surprising. Income derived from the Church was generally larger in the big administrative centres, which we might have expected to receive larger net-transfers. A look at the raw data suggests that in the earlier period this variable was driven by exceptionally large income from the sale of Jesuit property in the early years after their expulsion. Thus we would not put too much weight on this result. Districts with higher military spending received larger net transfers, though this variable is not driving the story as strongly as the historiography suggests. A peso of additional military

\footnotetext{
${ }^{54}$ The fact that all revenue categories (mining, trade and consumption, agriculture, church) have negative signs in the first period is slightly counterintuitive at first sight; we thank Daniel Tirado for raising this point. However, it is explained by a bias in the sample created by data survival. In theory, net intra-colonial transfers between cajas should add up to zero. But we know from tables 1 and 2 that net recipients are underrepresented because we miss the Caribbean, the North American presidios, part of New Granada and the Philippines. There is no easy correction for this problem. For our purposes, however, it is much more important that we represent the net payers correctly. This is the case since the sample includes the most populated areas and the silver producing ones. As a consequence we agree that the size of the individual coefficients might be affected by the sample bias, but we are confident that the ranking between independent variables with regard to the likelihood of paying more into the transfer system is robust.

${ }^{55}$ James Mahoney, "Long-Run Development and the Legacy of Colonialism in Spanish America," American Journal of Sociology 109 (2003)., p.85. We are somewhat agnostic about Mahoney's results, which are based on relatively weak author coded data and employ a weak statistical test. We also think that his model is mis-specified without the inclusion of revenue transfers.
} 
spending in peace time was associated with 0.4 pesos of more net transfers. Neither mining nor military needs nor transfers to Spain determine the results to the extent that the traditional story would make us believe. Instead, seaports received huge net transfers, about 350,000 pesos on average compared with the average net income of cajas in this period was about 770,000 pesos. ${ }^{56}$ The results show that sea ports were associated with higher net transfers even if we control for the impact of defence needs.

These results also hold true if we include as an additional variable the transfers to the metropolis in regression 2. Those districts that did transfer funds to Spain received smaller net-intra colonial transfers. The coefficient is not large but it illustrates that the system of intra-colonial transfers functioned largely independently of any transfers to Spain. Introducing remittances to Spain does not change the coefficient for seaports notably. Again, we interpret this as evidence that seaports did receive intra-colonial transfers independently of being or not regions from which remittances to Spain were shipped. It seems that seaports attracted intra-colonial transfers due to their role in international trade alone not because they had larger military needs or organised remittances to Spain. The results also confirm that transfers to Spain were not the pivotal part of the system of re-distribution of resources. Instead the fiscal system in Spanish America evolved around a system of distribution of funds between macro-regions within the colonies on the one hand, and within those macro-regions on the other, causing in some cases a substantial geographical split between regions of tax collection and regions where the expenditure took place.

By the late 1790s the fallout from the European wars was also increasingly felt in the colonies. Local defence spending increased when

${ }^{56}$ It should be noted though that size distribution was very large ranging from incomes of a few thousands to 40,000,000 pesos in Mexico City. 
the colonies came under threat and intra-regional transfers increased ${ }^{57}$ Fiscal pressure intensified and net-transfers were channelled more directly into areas responsible for military and naval expenditures as the results of regressions 3 and 4 illustrate. Pressure for extra revenues to fund higher expenditures on defence was not - it seems from our regression analysis - intensified for mining and agriculture or major areas of administration. Extra burdens in wartime fell on domestic trade and consumption; seaports escaped with some reductions in net transfers. What emerges here is a picture rather different from the story of an extractive economy. Under strain net-flows of transfers shifted. Previously they had been quite evenly distributed between regions deriving their revenues from different sectors though unevenly distributed geographically. Now, revenue from trade and consumption taxes, especially that derived from internal commerce, became strongly associated with net-outflows of transfers. The amount of revenue derived from agriculture and mining on the other hand ceased to be statistically associated with the flow of net-transfers.

This is a very interesting finding: In an allegedly extractive economy ruled by an absolutist predator state (fiscus) the main source of revenues was trade and consumption within the domestic economy. Latin American historians have stressed the significance of domestic trade in the colonial economy following Sempat Assadourian's seminal contribution. ${ }^{58}$ However, a cruder picture of the imperial economy and its rule portrayed elsewhere resulted in many economic historians overlooking the scope and strength of non-metal production and overall commerce in the interior

\footnotetext{
${ }^{57}$ Marichal, La bancarrota.; O'Phelan Godoy, "Las reformas fiscales."; J.J. TePaske, "The financial disintegration of Royal Government of Mexico during the Epoch of Independence," in The Independence of Mexico and the Creation of the New Nation, ed. J. Rodriguez O (Los Angeles and Irvine, 1989).

${ }^{58}$ Assadourian has estimated that even in the $16^{\text {th }}$ and $17^{\text {th }}$ centuries, 40percent of the total silver extracted in Peru remained in circulation in the colonial economy. Carlos
} 
of the colonies. Overall then, our regressions suggest that the traditional picture of Spanish rule is untenable. In peace time, we can all but reject the hypotheses of a system geared towards extracting revenue from mining and channelling it to Spain. There is some evidence that agriculture was subject to some 'extractive' pressure and that revenue was targeted at defence, but neither is sufficient to explain the nettransfer system entirely. In war time, the defence hypothesis has more support from our results, but the 'extraction' hypotheses have to be even more strongly challenged.

It may also be instructive to consider the sample of a few treasury districts, listed in table 6 below, where we know that mining was definitely the predominant sector in that district in order to assess the role of mining for the overall collection of revenue. By the late 1790s, mining districts received overall about 50 percent of their receipts (excluding intra-colonial transfers) from mining, down from 58 percent ten years earlier. Mining districts attracted extensive sectors for agricultural production to supply the workforces. In a number of mining towns the share of taxes levied upon agriculture was close to or even higher than taxes collected directly from mining. However, in many mining districts trade and consumption contributed a rather large share of the income. In fact, the fall in the relative share of revenue derived from mining between the late 1780 s and the late 1790 s by eight percent was accompanied by a corresponding rise in the share of income from the respective second most important sector. If we take the respective second largest sector, in most cases, trade and consumption, in a few, agriculture, we observe that by the late 1790 s it contributed on average more than 30 percent to the total non-transfer income of these main mining centres. In places like San Luis Potosi (New Spain) trade contributed as much as mining.

Sempat Assadourian, El sistema de la económia colonial. El mercado interior, regiones y espacio económico (México, 1983). 
Table 6: share of non-transfer tax revenue in major mining centres derived from mining and second most important sector 1796-1800. In percentages.

$\begin{array}{lrcc}\text { Caja } & \text { Mining } & \text { Trade\&Consumption } & \text { Agriculture } \\ \text { Arica } & 68.96 & 29.79 & \\ \text { Carangas } & 31.94 & & 44.44 \\ \text { Oruro } & 39.87 & 13.64 & 25.84 \\ \text { Potosi } & 58.63 & & 45.59 \\ \text { Trujillo } & 39.28 & & 10.09 \\ \text { Vico Y Pasco } & 69.41 & & \\ \text { Bolaños } & 38.55 & 58.34 & \\ \text { Durango } & 65.16 & 18.42 & \\ \text { Guanajuato } & 60.10 & 16.14 & \\ \text { Pachuca } & 47.68 & & \\ \text { Rosario } & 40.32 & 41.10 & \\ \text { San Luis Potosi } & 41.33 & 39.03 & \\ \text { Sombrerete } & 43.74 & 30.75 & \\ \text { Zacatecas } & 65.38 & 25.68 & \\ \text { Zimapan } & 58.99 & 26.20 & \\ \text { Chucuito } & 19.32 & & \end{array}$

Over a period of increased fiscal pressure the share of non-mining income increased considerably, suggesting a shift in the relative burden. We see clear evidence that the largest sector in these mining areas was over time paying a smaller proportion of total tax revenue. ${ }^{59}$ Since we have no way of knowing how large each sector in any of the individual districts was we can only offer conjectures. Yet, the sample of mining towns casts doubt over the assumption that the contribution that each sector made to total income was strongly correlated to its share of the local economy. For example, by the late $18^{\text {th }}$ century Buenos Aires was

\footnotetext{
${ }^{59}$ The relative decline in mining taxes was clearly not driven by a decline in the sector, which was very prosperous at this time. See Rafael Dobado, "El Monopolio estatal del mercurio en Nueva Espana durante el siglo dieciocho," Hispanic American Historical Review 82 (2002). and Richard L. Garner, "Long Term Silver Mining Trends in Spanish
} 
maturing into a major maritime city. Yet, of the taxes collected for the district only 3-4 percent of total revenue came from taxes levied on trade and consumption. This and other examples qualify representations of an implied fiscal system servicing the needs of the metropolis. Our data set and analysis suggests a system marked by negotiations over taxes between social elites (mining, landowners and merchants) and the metropolis. ${ }^{60}$ The absolutist history of an all powerful king and his bureaucracy is a myth. An alignment in fiscal policy between the interests of elites and crown is the key to understanding how the Empire survived as a single political unit for 300 years in the face of superior military power from its rivals.

The data presented above are consistent with this perception. Powerful mining elites in the silver districts and mercantile elites in commercial centres knew how to avert and avoid impositions on their incomes and economic activities. When the state demands for revenues went up the burden was rolled over onto softer targets, such as trade and consumption or agriculture in mining towns, where a large and cash-rich population lived. Most of the small settlements in the interior (stretching from the coast to the highlands) organised around the local production of foodstuffs, services and some manufactured goods sold to urban or mining centres obtained most of their income from the intermediation of goods from foreign (European, Oriental) or interregional or locally produced commodities. Here local interests were often too weak to resist taxation. By contrast, commercial elites from maritime cities kept their taxes low and fostered trade. More trade made commercial elites more powerful and resourceful in their defence of commercial and fiscal

America. A Comparative Analysis of Peru and Mexico," The American Historical Review 93 (1988).

${ }^{60}$ See also Irigoin and Grafe, "Bargaining for Absolutism.". 
privileges and transfers from other less advantaged regions picked up the tab not only for defence but for much of civil administration as well.

Transfers augmented supplies of money and credit in port cities like Buenos Aires, Havana or Cartagena. ${ }^{61}$ The latter received about 17 million pesos from the interior regions in New Granada over the period 1776-1810, roughly 25 pesos per capita for the whole district population, or 119 pesos extra for every inhabitant of the port. For Cuba the economic effects of transfers were even more spectacular. The free population of the island had increased by 46 percent in these 15 years and the slave population doubled. Meanwhile in Buenos Aires and Havana yields from customs increased 10 times from 1778 to 1803-05. This is the lowest bound estimate at least for the increase in trade since contraband was the norm in the River Plate. ${ }^{62}$

The performance of colonies with such different factor endowments - one with abundant free land and scarce labour in the remote River Plate and the other located in the Caribbean basin specialised on labour intensive commercial agriculture: the sugar island Cuba - with dissimilar sets of property rights to labour and land - expensive free labour in the former and slavery in the latter - was extraordinary. ${ }^{63}$ John Coatsworth has explained their superior rate of growth (in contrast with other Spanish American settlements) in terms of their openness to overseas trade. Apart from the inclusion of re-exports in the index of openness this neoinstitutional explanation fails to mention that both economies (like Cartagena in New Granada and other smaller ports elsewhere in Spanish

\footnotetext{
${ }^{61}$ The following pages draw on Irigoin, "Bringing the New World Back.", Irigoin and Grafe, "Bargaining for Absolutism."

62 Irigoin, "Bringing the New World Back.". The free population in Cuba in 1774 was: 128,287 and 187,711 in 1792 . The slave population in the same period moved from 44,333 to 84,590 . Buenos Aires' population at the city port grew from 24,205 inhabitants in 1776 to about 40,000 in the 1800s. Cubans increased their spending on foreign goods (Spanish, from other colonies and from outside the empire) from 18 pesos per free person to 57 pesos in 1792 not withstanding the rapid population increase in the period.
} 
America) were net recipients of transfers of revenues in silver from distant interior regions. This additional liquidity fostered trade, improved purchasing power of exports, and created subsidies for consumers and additional revenues from trade.

Table 7 Annual net transfers per capita for selected treasury districts 1796-1800 (pesos)

\section{Caja}

La Paz

Potosi

Mendoza

Buenos Aires

Catamarca

Corrientes

Salta

San Juan

Santa Fe

Santiago del Estero

Tucumán

La Rioja

Arequipa

Cuzco

Huamanga

Lima

Trujillo

Durango

Guadalajara

Guanajuato

Mexico

Oaxaca

Puebla

San Luis Potosi

Zacatecas
Net transfers pc

$-5.72$

4.75

$-0.16$

19,85

$-0.08$

$-0.03$

0.00

0.00

$-0.11$

0.00

$-0.05$

$-0.03$

$-3.34$

$-5.17$

$-5.03$

6.67

$-10.22$

$-2.54$

$-1.21$

$-1.74$

$-2.81$

$-0.50$

$-0.09$

$-2.68$

$-4.91$

The overall scale of additional resources pumped into a few areas by way of re-distribution of revenues within the empire have been

${ }^{63}$ Coatsworth, "Economic and Institutional Trajectories.". 
measured for districts for which population data are also available. The results are clear. While a great many districts paid moderate amounts of net transfers, a smaller number of places received large per capita subsidies. Per capita figures illustrate where and to what degree fiscal transfers mattered. To understand by how much purchasing power in the receiving districts increased it is useful to put them into the context of contemporary spending power. Brown calculates that the annual spending of a Spanish family in Arequipa (Peru) was about 260 pesos in 1780 and 240 pesos in 1800; for a mestizo family he assumes 160 and 130 pesos respectively. ${ }^{64}$ Transfers of 20 pesos or more per annum to places like Havana, Buenos Aires and Cartagena enriched and empowered elites in both sending and receiving region because the management of transfers remained in the hands of mercantile interests who used public funds to finance trade and to make gains from arbitrage and commissions. ${ }^{65}$ For example, Potosi merchants took the annual situado to the port of Buenos Aires to finance their purchase of imported goods. Merchants from Mexico City took the revenues to Havana by paying themselves for military supplies and many other goods they transported to that city.

The fiscal inequalities that this system produced in the interior of the Empire in America by the early $19^{\text {th }}$ century were to a large extent the outcome of a man-made phenomenon. The intra-colonial transfers altered substantially the spatial availability of resources for investment and consumption, in accordance with the changing rhythm of global trade. Note the relative change in the transfers to Lima (sent forward to Panama, Acapulco and the Pacific), in favour of remittances to the port in the South Atlantic (Buenos Aires, from where silver reached China and

\footnotetext{
${ }^{64}$ K.W Brown, "Price Movements in 18th century Peru - Arequipa," in Essays on the price history of 18th century Latin America, ed. Lyman L. Johnson and Enrique Tandeter (Albuquerque, 1990), pp.189/190.

${ }^{65}$ Irigoin and Grafe, "Bargaining for Absolutism.".
} 
the East Indies). ${ }^{66}$ The system of fiscal re-distribution between treasury districts served its purpose from the point of view of the Spanish Empire. It funded military defence, it made the colonies self-sufficient, and it kept local elites' interests aligned with those of the crown by fostering a remarkable economic growth at least in the $18^{\text {th }}$ century in some colonies. Yet, it also made different parts of the colonies dependent on one another. And then disaster struck in the person of a Frenchman.

\section{The role of Contingency: History matters}

In May 1808 Charles IV was imprisoned by French troops. Napoleon placed his brother Joseph on the throne of Spain and demanded that the regular transfers of silver be continued as before. This conjuncture led via revolutions to the birth of modern republics in Spanish America. ${ }^{67}$ With the deposition of the Spanish king the ultimate arbiter for a system of revenue re-distribution between colonial districts, which had existed for some three centuries, collapsed and the empire imploded into strife over revenues in the colonies.

This "sudden and to large extent accidental" event opened the transition in the colonies and the metropolis to the modern representative state. ${ }^{68}$ The transition was lengthy and costly. Certainly the imprisonment of the king and the abduction of the heir by Napoleon, incidental as they may look, concurred with an intense bargaining between a financially impaired crown and stronger-than-ever local oligarchies about a

\footnotetext{
${ }^{66}$ Irigoin, "Bringing the New World Back.". Lima, and the overall economy of Peru, reached its peak of splendour and prosperity in the first half of the $17^{\text {th }}$ century, and declined over the $18^{\text {th }}$ century. Contrarily, the establishment of the new Viceroyalty in the River Plate, in the south Atlantic echoed the contemporary expansion of Atlantic trade, and of the Dutch, English and North American merchants visiting the colonial ports in South America.

${ }^{67}$ J. Rodriguez O, Independence of Spanish America (Cambridge, 1998)., David Bushnell and N. Macaulay, Emergence of Latin America in the 19th century (Oxford, 1994).
} 
redefinition of imperial policy making inaugurated with the Bourbon reforms and Spain's involvement in the European wars. Local society in the main colonies was reaching a point of maturity in which structural social, ethnic, economic and regional tensions were incipient and challenging already the continuation of the colonial social order. Spanish American elites only "needed a favourable conjuncture in which to seize the initiative" to assert their clout, ${ }^{69}$ and the overall crisis of governance caused by Napoleon's invasion to Spain proved to be the best catalysts.

The process has been widely studied by political and economic historians of Spain and Latin America. ${ }^{70}$ Moreover, the distinct path that the Portuguese empire followed, in similar circumstances, has been taken as confirmation of interpretations for Spanish American political independence. Able to flee from occupied Portugal, with the help of the British navy, the Portuguese crown established itself in Rio de Janeiro, which became the capital of the empire and the colony thereafter. The survival of the Portuguese monarchy explains the continuation of the unity and of imperial rule in Brazil in contrast to the political fragmentation of Spanish America into a number of republican states. ${ }^{71}$

\footnotetext{
${ }^{68}$ Guerra, "Spanish American Tradition," p.5.

69"Spain had been living dangerously since 1796". Lynch, "Institutional Framework," p.107.

${ }^{70}$ Guerra, "Spanish American Tradition.", T Halperin Donghi, "The Crisis of Independence," in The Contemporary History of Latin America (Durham, 1993), Halperín Donghi, "Backward Looks.", Lyman L. Johnson and Susan Migden Socolow, "Colonial centers, colonial peripheries, and the agency of the Spanish state," in Negotiated Empires. Centers and Peripheries in the Americas, 1500-1820, ed. Christine Daniels and Michael V. Kennedy (New York and London, 2002)., Lynch, Colonial Roots.; David R. Ringrose, Spain, Europe, and the "Spanish Miracle," 17001900 (Cambrdige and New York, 1996).; Frank Safford, "Politics, Ideology and Society," in Spanish America after Independence, c 1820-c 1870," in Spanish America after Independence, c.1820-c.1879, ed. L Bethell (Cambridge, 1987).

${ }^{71}$ The social and political disruption that Napoleon provoked in Brazil was minimal. The country achieved Independence from Portugal when Emperor Joao VI left the New World for Lisbon in 1821, when it was safe from the French. His son Pedro I declared the independence of Brazil within a very similar politico - institutional set up, the empire of Brazil. Nevertheless, Portuguese imperial rule in America had been more interventionist and accorded greater power to the Portuguese bureaucracy. Lynch, Colonial Roots. pp.94-5., L. Bethell and N. Macaulay, The emergence of Latin America
} 
The crisis of governance, indeed a crisis of legitimacy and of political authority challenging the survival of Spanish rule in the New World, mirrored similar turmoil in Spain. Nineteenth century Spain witnessed a sequel of "coups, countercoups, civil wars, restorations and constitutional experiments" not unlike its republican offspring in mainland America. ${ }^{72}$ Such a common path in the metropolis and the colonies points to the very nature of the Spanish political constitution, and the effects of the events of 1808: they resulted in a crisis that brought down the Monarquia Universal of the Catholic King and the empire altogether, undermining the foundations of authority and legitimacy of the crown. In Spanish America, 1808 opened a "general frenzy of traditionalists, as it was carried out in the name of historical legitimacy, of the king, religion and traditions" in reactions to the prospect of French rule or the rule of an illegitimate sovereign, the self-appointed regency that emerged in Cadiz. ${ }^{73}$ Thus, Creoles and peninsulares contended to organise caretaker governments in the name of the imprisoned king claiming a legitimate right to sovereignty. Both factions, mixed in some colonies, more distinguishably in others, struggled to control the institutions of legitimate

in the nineteenth century (Oxford, 1994). pp.15-16., Halperin Donghi, "The Crisis of Independence," pp.71-72. Brazil's institutional trajectory during the $19^{\text {th }}$ century was quite different from that of former Spanish colonies: Independent, if imperial, Brazil was much more stable as the empire and slavery continued to survive until late 1880s.

72 "Even the consensus that had legitimised the monarchy was destroyed, divisions among pre-bureaucratic modernizers worsened. The credibility of the traditional monarchy was further eroded by the existence of numerous claimants to the role of sovereign after 1808. Among them we find three kings, Charles, Ferdinand and Jose I Bonaparte, the regency government in Cadiz and the provisional regional juntas that assumed authority in the absence of a central government at the same time that the collapse of the empire paralysed commerce at Cadiz and destroyed the fiscal system of the Crown. Restricted to the peninsular revenues, its $18^{\text {th }}$ century alliance with reforming bureaucrats in ruin, the monarchy restored in 1814 lacked political autonomy. As the impoverished crown lost its ability to manoeuvre between interests groups, control of policy became a football that passed from one to another coalition". Ringrose, Spain, Europe, and the "Spanish Miracle," 1700-1900. p.319, 323.

${ }^{73}$ Having opened the door to Spanish American representation in the Congress of Cadiz, "what led to Independence of South America was the rejection of equal representation between the two parts of the kingdom," Guerra, "Spanish American Tradition," p.5. 
authority over the territory, to regain the sinews of the empire: the regional treasuries and mint houses. What followed, in the words of Halperín Donghi, was a "civil war" among opposing factions of the colonial elites. The result was an increasing territorial, political and hence fiscal fragmentation of the empire. ${ }^{74}$

As indicated, the literature on the politics, the ideology and the institutional developments of Independence in Spanish America is wide and sophisticated. Yet, "the reasons for the fragmentation of Latin America are not quite evident." ${ }^{75}$ Allegedly pre-existing regional and ethnic identities or different economic and regional interests collided once the "ultimate power of decision making" disappeared in $1808 .{ }^{76}$ Traditional historians had identified competing interests within the colonial elites, whether Creoles displaced from office or mercantile interests associated with the Cadiz monopoly who were prejudiced by the freer trade policies. More recently, historians of Independence relate the crisis of legitimacy and representation opened in 1808 to the multiplication of demands and rivalries among regions with an increasing sense of nationality and very different economic interests, and assets, for a successful integration into the expanding Atlantic economy.

\footnotetext{
${ }^{74}$ Halperin Donghi, "The Crisis of Independence," p.51. He also emphasises the conservative inspiration of the revolution in Buenos Aires, Venezuela and the Andes. See also Safford, "Politics, Ideology and Society," in Spanish America after Independence, c 1820-c 1870," p.57., Bethell and Macaulay, Emergence., Lynch, Colonial Roots. p.57.

${ }^{75}$ For the authoritative historians of the nineteenth century, Bethell and Macaulay, Emergence. p.22.

${ }^{76} \mathrm{Ibid}$. p.26. A similar characterisation of Spanish rule is offered by Ringrose. "The political culture of Ancien Regime Spain had inculcated general acquiescence in the legitimacy of a pre-Lockian paternalism that defined the moral authority of the crown and legitimised its occupant as the ultimate arbitrator and source of legislation" Ringrose, Spain, Europe, and the "Spanish Miracle," 1700-1900. .p.320.. The King was in this system the "arbiter of last resort whose approval all forces needed if their successes were to be legitimised" Halperín Donghi, "Backward Looks." "And the state was embodied in the patrimonial power of the king, who was not the only source of all patronage but also the ultimate arbiter of all disputes. Without the presence of the king, the system shattered" Safford, "Politics, Ideology and Society," in Spanish America after Independence, c 1820-c 1870," p.115.
} 
Our discussion offers another response to the reasons for the resulting political developments of post-independent Spanish America. With the collapse of the imperial rule, once the system entered a major legitimacy crisis, the massive redistribution of revenues that underpinned the imperial system ceased almost immediately to exist opening a process of increasing fiscal and political fragmentation. As mentioned above, the break-up of the empire occurred along the lines of territories where the regional treasuries were located. ${ }^{77}$ Political fragmentation and the disintegration of the system were intimately connected. Regional elites seized colonial revenues immediately to defend their political and economic interests and in time to define the fiscal boundaries of new republican states. Called upon to fund either patriot or royalist local treasuries, particularly those that had depended upon transfers, fell into serious disarray. Fiscal revenues and mint houses fell into the hands of new local authorities or the "private sector" and broke free of all traditional obligations to the "Spanish" Empire. Disorder and civil war were unavoidable when new governments concentrated on sites and boundaries of former colonial tax districts, which had been components of a imperial fiscal network responsible for and distributor of revenues for Spanish America. New political units, provinces or states, became to a great extent fiscally and politically autonomous. Some remained bound to each other in loosely defined constitutional (federal, confederate) national states. More often though, they engaged in the continuous warfare that characterised nineteenth century Latin American political development. ${ }^{78}$

\footnotetext{
${ }^{77}$ Bethell \& Macaulay signal the same process in the territories where the colonial system had "the separate high courts or audiencias". They also point to some exceptions to this rule, like the River Plate. Bethell and Macaulay, Emergence. p.24. Indeed the immediate territorial dis-aggregation and the emergence of political and fiscal autonomous entities corresponded to the sites of the cajas.

${ }^{78}$ Safford points to the roots of the political conflict in the fight to "determine who would control the state and its revenues", whereas there was no similar conflict about economic or fiscal policies (which) "were no part of a party of factional issue." Safford, "Politics, Ideology and Society," in Spanish America after Independence, c 1820-c
} 
Beggar thy neighbour strategies flowed from the collapse of an imperial fiscal system that had worked well for centuries.

The compact and consensus that had existed in Spain and its colonies had to be rebuilt from scratch. The resulting disorder and instability revolved around the creation of new fiscal as well as political constitutions both in the metropolis and each of the colonial main treasuries. Thus, it could be argued, that the malign legacy of Spanish imperial rule in America was not due primarily to its absolutist nature. Rather a unique system of internal re-distribution of revenues created strong centrifugal tendencies in the absence of the ultimate and legitimate arbiter. In North America a new nation state emerged out of the aggregation of quasi-autonomous, self-governed, fiscally independent colonies. In Spanish America an operational unified political and economic empire collapsed into a large number of poorly defined and legitimated nation states. The Spanish path to the formation of an empire turned out to be a poor basis for state formation and institution building in the post-independence period.

\section{Conclusions}

We started this paper with a discussion of the merits and flaws of a now very extensive literature that compares former Spanish and British colonies in order to identify the conditions that favour - or hindered economic growth in the longer run. As Engerman and Sokoloff point out, the Americas are in some senses a natural experiment that can enlighten many of the larger issues of long-term growth. We argued that, broadly,

1870." P 84, 87. Thus, "international" wars between Bolivia and Chile about nitrates, or Chile, Bolivia and Peru about exports by mid-century were a competition with (each) other for those resources that would allow (a country) to continue its "rents." M. A Centeno, "Blood and Debt. War and Taxation in nineteenth century Latin America," American Journal of Sociology 103 (1997): .p.1589. 
two approaches have developed. One sees the origins of North American success and Latin American failure in the institutions that were introduced by the respective colonial overlords. The other is more deterministic and sees the root of differential development in the natural endowments that European colonisers found in their newly conquered territories. These it is argued created a much greater degree of inequality in the Spanish hemisphere, which became enshrined in the institutional set-up of these colonies and their successor states and thus perpetuated itself.

The insitutionalist approach claims that Spain's predatory absolutist state forced the colonies into an economic development based on the exploitation of natural resources and indigenous labour. This in turn created an economy rife with rent-seeking which stifled investment and production and in the longer term seriously constrained Latin America's growth potential. In section 1 we have confronted this claim with the reality of the structure of the fiscal system in Spanish America. We have argued that the colonies far from being at the mercy of a powerful extractive machine in the form of a strong colonial bureaucracy were in fact surprisingly autonomous in fiscal terms. The lack of a single fiscal constituency, of uniform tax rates, of centralisation of the system all point in the same direction: the tax system in the colonies depended to a very large degree on local and regional decision-making. The relationship between the crown and colonial elites was one of negotiation not of command. The murky reality of Spanish colonial fiscality shows clearer than any other indicator that it is wrong to depict Spanish colonial rule as absolutist, bureaucratic and extractive in the ways the institutionalists have done.

The factor endowment approach returns more to economic fundamentals, namely the availability of land, labour and raw materials, that existed in the respective colonies. Here it is argued that Spanish colonies, blessed with large amounts of silver and labour, featured a very 
unequal income distribution from the very beginning as a consequence of the concentrated control over these valuable resources. Over the course of 300 years of colonial rule this unequal distribution became enshrined in the political and social institutions of the colonies reducing investment and ultimately damaging growth. Factor endowments obviously provided for great differences in the economic potential of Spanish colonial districts. However, in section two we have argued that an analysis of the fiscal setup of the colonies shows that we can understand their impact only if we understand the nature of Spanish rule. Again, as in the case of the insitutionalist approach we feel that the way Spanish rule is characterised is inaccurate.

What our analysis of the colonial Spanish America fiscal data show is that this was not a system primarily aimed at the extraction of resources or revenues from the colonies for the benefit of the metropolis. Instead it aimed at making the colonies self-sufficient and the Spanish empire was successful in that. But self-sufficiency was only possible because intra-colonial transfers covered the needs of those regions that either could not or would not raise sufficient revenue to pay for their defence and administrative expenditure. In this sense, Spanish colonial rule did the job well - the transfers enabled the empire to expand into unsettled territories from the Californias to Patagonia, with presence and commerce in both oceans. It defended itself against enemies that were militarily superior at least by the late $17^{\text {th }}$ century and let the colonial economy grow at a reasonable rate. Yet, again it is important to keep the political economy foundations of this system in mind. It worked because within a negotiated rule the alignment of interests between local elites and crown kept it working. This depended crucially on the king as the accepted ultimate arbiter of the system. Once we have established the role of the crown within this institutional set-up it becomes clear why the 
system was thrown into total disarray in the aftermath of the imprisonment of the Spanish king at the hands of Napoleon.

With the abduction of the king, the common source of sovereignty of the empire and the system of intra-colonial transfers collapsed. In its wake, conflict between districts that had depended on transfers and those that had been net payers was unavoidable. The break-down of the system meant that many cajas could not sustain their spending without transfers; the unequal distribution of the tax burden - both in regional as well as in sectoral terms - became apparent when each new polity located at the old fiscal districts scrambled for the means to carry on. This suggests that economic causes, the income shortfall and the needs for new sources of revenues in these cajas drove the political and military conflicts that plagued Latin America after Independence. We suggest that the causality between economic strain and political conflict was exactly the opposite of that suggested by the institutionalists, who claimed that political strife, disorder and instability in the aftermath of independence determined the poor economic performance of modern Latin America in the $19^{\text {th }}$ century. But our story is not one of a re-distribution of resources on the basis of factor endowments either. The unequal access to fiscal resources that caused the political strife during and after independence was largely man-made. It was the outcome of intra-colonial transfers and the estrangement that followed the novelty of having a ruler who was impeded to rule not of simple resource endowments.

Ultimately our reading of the fiscal and political history of the late colonial and early post colonial phase in Latin America puts the importance of contingency - history - back centre stage among normative theoretical arguments. The complex fiscal system of cross-subsidisation of treasury districts in colonial Spanish America owed a lot both to resource endowments and to the negotiated character of Spanish rule. Yet, it was a chance event, the imprisonment of a king that created a 
vacuum in the legitimate authority of the ruler, which brought the whole system down. Because regions had depended on one another this was the one shock the system could not withstand. Economic conflict over revenues led to interregional war and territorial fragmentation. The latter in turn destroyed the western world's largest customs and monetary union reinforcing the fragmentation of previously integrated markets further cutting off regions from vital supply lines and centres of demand..$^{79}$ The economic cost was huge. Indirectly we could blame Spanish institutions for them, but only insofar as they created a system that was successful as long as common legitimate rule was uncontested but created incentives for regions to use beggar-thy-neighbour strategies when that common sovereignty was destroyed through a truly external shock.

\footnotetext{
${ }^{79}$ This point has been ignored for a long time. Exceptions were for the case of Mexico Marichal, La bancarrota. and for Latin America Irigoin, "Macroeconomic aspects.". See also Leandro Prados de la Escosura, "Colonial Independence and Economic Backwardness in Latin America," Carlos III Depto de Historia Económica working paper (2004). and Luis Bértola and Jeffrey G. Williamson, "Globalization in Latin America before 1940," NBER working paper 9687 (2003).
} 


\section{$\underline{\text { Appendix } 1}$}

The data for the analysis of the treasury districts are derived from the accounts transcribed and published by J.J. TePaske and H. Klein available in print and online. The geographical area covered includes the Viceroyalties of Rio de la Plata and Peru as well as New Spain, i.e. today's Argentina, Uruguay, Paraguay, Chile, Bolivia, Peru and Ecuador. Missing is data for New Granada, today's Columbia, Venezuela and Central America. Data cover the entire colonial period. However, there are many more missing accounts for individual districts in the earlier period than in the later ones.

Of the 72 local treasuries studied over a period of more than 250 years, 14 cajas were created before 1600, corresponding to Mexico and Veracruz (1520s), Cuzco and Lima (1530s) Santiago de Chile, Merida and Guadalajara in the 1540s, Potosi, Zacatecas and Huancavelica in the 1550-70s, Durango, Acapulco, Arequipa and Arica by the 1590s. Another 17 cajas were created during the $17^{\text {th }}$ century. Between 1700 and 1760 ten new cajas were established, and from the reign of Charles III in the 1760s 27 more treasury districts appeared. Eighteen of these were established in the newly created Viceroyalty of the River Plate along the route the silver took to the Atlantic from Potosi to Buenos Aires. The others were created in the outer regions of New Spain where North American merchants obtained silver. In the north of Mexico Chihuahua and Saltillo became cajas, and around the Campeche bay in the Gulf of Mexico: Arispe and Rosario, in California San Blas. Only two cajas were abolished or superseded in the $17^{\text {th }}$ century and eight in the $18^{\text {th }}$ Peru, only two cajas were abolished in the $17^{\text {th }}$ century: Castrovirreyna and Chachapoyas. Cuba had 23 cajas and in New Granada there were 18, 
four main ones (Cartagena, Bogotá, Popayan and Panamá), which gathered 67 percent of total royal revenues. ${ }^{80}$

The choice of time periods was based on considerations both of quality of data as well as historical events. An earlier sample would have been desirable but survival of the data was such, that the consistency of the results would have been suspect. Both periods 1785-89 and 17961800 are at least a number of years after the large uprisings in Upper Peru that had seriously impacted on tax collection. They also cover a period that is generally understood to have been that of the major impact of the Bourbon Reforms but fall in the period before the first conflicts that would lead to Independence. Compared to the first sample the second reflects already the increasing pressure for resources that the Spanish Crown must have felt in the European Wars.

In terms of availability of data there are only relatively few missing observations (considering an average of 61 possible accounts in each year): Sta Cruz de la Sierra, Corrientes, Maldonado, Puebla, Michoacan in 1785; Sta Cruz de la Sierra, Corrientes, Puebla, Michoacan, La Paz, Carabaya, Jauja in 1786; Puebla, La Paz, Jauja, Catamarca, Stgo de Estero, Durango, Chihuahua in 1787; Sta Cruz de la Sierra, Puebla, La Paz, Jauja, Presidio del Carmen in 1788; Maldonado, Carabaya, Jauja in 1789; Chihuahua, Chucuito, La Rioja in 1796; Oruro, Tucumán, Chucuito, La Rioja, Catamarca, Carabaya, Merida in 1797; Catamarca, Tucumán, La Rioja, Carabaya in 1798; Charcas, Chucuito, Carabaya, Presidio del Carmen in 1799. Except for Charcas, Puebla, and La Paz these were not major treasury districts.

${ }^{80}$ For Cuba see John Jay TePaske, "Integral to Empire. The Vital Peripheries of Colonial Spanish America," in Negotiated Empires. Centers and Peripheries in the Americas, 1500-1820, ed. Christine Daniels and Michael V. Kennedy (New York and London, 2002), p.32. For New Granada see J. Jaramillo, Adolfo Meisel, and M. Urrutia, "Continuities and Discontinuities in the Fiscal and Monetary Institutions of New Granada," in Transfering Wealth and Power from the Old to the New World, ed. Michael D Bordo and Roberto Cortes-Conde (New York, 2001). 
While these sorts of data are necessarily subject to errors, most of the criticisms against their use have been directed at how well they can represent the 'real economy' behind them. Therefore, we explicitly refrain from interpreting them as a mirror of the actual size of sectoral composition of the treasury districts. But we argue that they do tell us something about which sector of the economy was contributing more to the fiscus and crucially how resources were transhipped from one district to the next.

The logic of TePaske and Klein's organisation of the information has to do with the way in which taxes were collected. This was most apparent in the case of revenues from trade and consumption, and from urban rather than rural sources of revenues. Taxes on mining and tribute were directly and proportional to the growth of output and of population and evasion was low. However taxes on trade and consumption were less effective and less tightly related to volume and values because of exemptions and changing bases or rates or lagged valuations. The situation was even more complex with regard to the various crown monopolies such as those on tobacco, pulques and azogue, and a myriad of other specific taxes and contributions. ${ }^{81}$ The accounts presented by Klein and TePaske for the individual treasury districts reveal strong local idiosyncrasies but we know too little about the incidence of these taxes to assess them properly.

In a first step, we tried to determine the net incomes and net expenditure for each caja and each year. For this purpose we subtracted all entries that relate to carry-overs and deposits from our net totals. Since it was not our aim to establish how much money these cajas actually had at any given point in time we left those amounts that were meant to be collected in a given year but not actually collected in the net totals of that years but subtracted all amounts collected in a given year 
but pertaining to previous or future years. By applying this routine to five consecutive years we hope that possible errors resulting from undetected carry-overs and the notorious delays in payments could be minimised.

We then re-classified every single item for each caja in order to analyse the composition. On the income side the overriding principle was one of tax incidence, i.e. which sector of the economy was likely to bear the burden of taxation. For this purpose we created the categories transfers, transfers to Spain, mining, agriculture, trade \& consumption, and church, the latter including the income from the so-called temporalidades, resources derived from the expropriated property of the Jesuits.

Our category "transfers" only includes payments from (income side) or to (expenditure) side other treasury districts in the colonies, not those from or to Spain. At times the destination/source treasury of transfers is clearly identified but often it is just registered as going to/coming from other districts. Thus it is impossible to closely follow the money trail through the districts. Klein and TePaske subsumed these in military expenditure, which we think clearly misrepresents them. Some districts have income classified as 'to Spain', clearly money collected by larger districts and earmarked for Spain, though it should be stressed that their amounts did not usually coincide clearly with the money actually registered as going to Spain on the expenditure side.

Some income headings were not easily allocated, in general we concurred with the categories given by TePaske and Klein's appendix, but amended them where necessary a) because our broad categories are differently defined or $b$ ) where TePaske and Klein do not reflect tax incidence. e.g. we argue that the Indian tribute would have burdened agriculture simply because it was paid by the Indian agrarian

${ }^{81}$ Klein, The American Finances. 
communities. As opposed to most authors we also include the monopolies according to their incidence, thus pulques are included in trade and consumption while azogues (mercury) fall into "mining". For each caja some sources remained unclassified either because they were indeterminate (such as hacienda en general) or because they belonged to administrative income, such as papel sellado or penalties collected by the courts, which could have burdened any sector.

Overall, however, more than 70 percent of all income was part of one of these categories while the remainder was mostly administrative income. In most cases our categories comprised more than 85 percent of income with a few extreme cases lowering the average. The latter were excluded from the analysis whenever sectoral information mattered. On the expenditure side we identified in addition to the transfers the amounts of money spent on military purposes and transfers to Spain. Overall, this process produced a data set with about 270 observations for each fiveyear period. 


\section{Appendix 2}

Table 3 Net transfers between Spanish American treasuries 1785-89, Spanish pesos.

\begin{tabular}{|c|c|c|c|c|c|c|}
\hline Caja & 1785 & 1786 & 1787 & 1788 & 1789 & $1785-1789$ \\
\hline Acapulco & $-136,607$ & $-86,926$ & $-201,861$ & $-112,294$ & 12,000 & $-525,688$ \\
\hline Arispe & 222,814 & 166,466 & 12,779 & 102,710 & $-64,391$ & 440,378 \\
\hline Bolaños & $-145,591$ & $-123,865$ & $-170,805$ & $-113,153$ & $-25,117$ & $-578,531$ \\
\hline Campeche & 82,285 & 22,032 & 18,966 & 0 & 0 & 123,283 \\
\hline Chihuahua & 27,667 & $-279,317$ & & 113,054 & $-355,068$ & $-493,664$ \\
\hline Durango & $-465,376$ & $-694,376$ & & $-134,003$ & $-78,719$ & $-1,372,474$ \\
\hline Guadalajara & $-864,411$ & $-258,043$ & $-457,038$ & $-517,639$ & $-453,203$ & $-2,550,334$ \\
\hline Guanajuato & $-1,160,293$ & $-521,560$ & 0 & $-1,135,915$ & $1,147,683$ & $-3,965,451$ \\
\hline Merida & 0 & -69 & -396 & 24,424 & 31,950 & 55,909 \\
\hline Mexico & $-1,699,584$ & $-1,795,432$ & $-3,748,611$ & $5,289,949$ & $4,370,736$ & $-16,904,312$ \\
\hline Michoacan & & & & 0 & 0 & 0 \\
\hline \multicolumn{7}{|l|}{ Oaxaca } \\
\hline Pachuca & $-74,883$ & $-107,315$ & $-156,074$ & $-85,331$ & $-129,257$ & $-552,860$ \\
\hline Pres del Carmen & 0 & 0 & 12,347 & & 0 & 12,347 \\
\hline Puebla & & & & & 0 & 0 \\
\hline osario & $-413,056$ & $-170,318$ & $-170,318$ & $-403,575$ & $-390,240$ & $-1,547,507$ \\
\hline \multicolumn{7}{|l|}{ Saltillo } \\
\hline San Luis Potosi & $-654,983$ & $-182,217$ & $-462,022$ & $-946,393$ & $-939,688$ & $-3,185,303$ \\
\hline Sombrerete & 0 & $-102,742$ & $-62,320$ & $-74,644$ & $-95,094$ & $-334,800$ \\
\hline Tabasco & $-2,774$ & $-6,457$ & 0 & $-10,446$ & $-8,660$ & $-28,337$ \\
\hline Veracruz & $-563,993$ & $-4,801,805$ & 483,413 & $-699,774$ & $-258,778$ & $-5,840,937$ \\
\hline Zacatecas & $-478,268$ & $-310,057$ & $-575,536$ & $-343,390$ & $-528,000$ & $-2,235,251$ \\
\hline Zimapan & $-78,496$ & $-47,609$ & $-58,036$ & $-52,629$ & $-49,718$ & $-286,488$ \\
\hline Net New Spain & $-6,405,549$ & $-9,299,610$ & $-5,535,512$ & $-9,678,947$ & $-8,850,402$ & $-39,770,020$ \\
\hline otosi & 33,621 & $-665,542$ & $-419,300$ & $-78,340$ & 325,241 & $-804,32$ \\
\hline Charcas & $-92,185$ & $-55,362$ & 6,010 & 19,040 & $-42,705$ & $-165,20$ \\
\hline La Paz & 0 & & 0 & & $-290,011$ & $-290,01$ \\
\hline Oruro & $-92,065$ & $-86,443$ & $-19,825$ & $-220,478$ & $-83,199$ & $-502,01$ \\
\hline Arica & $-37,200$ & $-75,250$ & $-67,946$ & $-73,412$ & $-58,590$ & $-312,39$ \\
\hline Carangas & $-48,866$ & $-10,770$ & $-12,788$ & $-20,855$ & $-8,000$ & $-101,27$ \\
\hline Cochabamba & 0 & 0 & $-30,653$ & 0 & 0 & $-30,65$ \\
\hline Chucuito & $-19,516$ & $-38,579$ & $-46,995$ & $-64,260$ & $-123,653$ & $-293,00$ \\
\hline Sta Cruz de la S. & & & 0 & & 0 & \\
\hline et Upper Peru & $-256,211$ & $-931,946$ & $-591,497$ & $-438,305$ & $-280,917$ & $-2,498,87$ \\
\hline Santiago de Chile & $-47,186$ & $-3,139$ & $-15,802$ & $-33,216$ & $-25,365$ & $-124,70$ \\
\hline Valdavia & 75,040 & 62,876 & 43,009 & 64,717 & & 245,64 \\
\hline Concepción & 180,054 & 197,662 & 163,322 & 128,248 & 168,524 & 837,81 \\
\hline Mendoza & 0 & 0 & 0 & 0 & $-1,650$ & $-1,65$ \\
\hline Chiloe & 16,000 & $-16,197$ & 1,504 & $-13,918$ & 31,985 & 19,37 \\
\hline hile & 223,908 & 241,202 & 192,033 & 145,831 & 173,494 & 976,46 \\
\hline s Air & $1,111,585$ & $1,563,373$ & $1,262,196$ & $1,168,050$ & $1,492,037$ & $6,597,24$ \\
\hline Montevideo & 78,652 & 47,204 & 60,394 & 78,652 & 44,001 & 308,90 \\
\hline
\end{tabular}




\begin{tabular}{|c|c|c|c|c|c|c|}
\hline Catamarca & $-1,019$ & 0 & 0 & 0 & -300 & $-1,32$ \\
\hline Cordoba & $-1,464$ & 0 & 0 & $-1,009$ & 0 & $-2,47$ \\
\hline Corrientes & & & 0 & 636 & 0 & 63 \\
\hline La Rioja & 0 & 0 & 0 & 0 & $-1,554$ & $-1,55$ \\
\hline Maldonado & & 15,000 & 59,020 & 6,000 & & 80,02 \\
\hline Paraguay & 0 & 0 & 0 & 0 & 4,350 & 4,35 \\
\hline Salta & 99,750 & 0 & 0 & 0 & 0 & 99,75 \\
\hline San Juan & $-1,583$ & $-1,138$ & 0 & & & $-2,72$ \\
\hline Santa Fe & 0 & 0 & 519 & 0 & $-13,343$ & $-12,82$ \\
\hline Santiago d Estero & 0 & 0 & & 0 & 0 & \\
\hline Tucumán & 0 & 0 & 0 & 0 & 0 & \\
\hline Net River Plate & $1,285,921$ & $1,624,439$ & $1,382,129$ & $1,252,329$ & $1,525,191$ & $7,070,00$ \\
\hline Arequipa & 86,301 & 9,356 & $-37,525$ & $-109,320$ & $-143,712$ & $-194,90$ \\
\hline Carabaya & 0 & & $-28,983$ & 11,016 & & $-17,96$ \\
\hline Cuzco & 0 & 0 & $-88,739$ & 17,394 & 55,693 & $-15,65$ \\
\hline Huamanga & 0 & 0 & 0 & 0 & 41,047 & 41,04 \\
\hline Jauja & $-17,035$ & & 0 & & & $-17,03$ \\
\hline Lima & 961,292 & $1,085,304$ & $1,598,264$ & $-970,135$ & $1,017,861$ & $3,692,58$ \\
\hline Trujillo & $-335,375$ & $-92,233$ & $-205,334$ & $-239,022$ & $-164,256$ & $-1,036,22$ \\
\hline Vico Y Pasco & $-81,094$ & $-100,387$ & $-150,179$ & $-120,163$ & $-251,550$ & $-703,37$ \\
\hline Quito & $-222,099$ & 633 & 1,404 & 0 & 64,689 & $-155,37$ \\
\hline Guayaquil & $-97,912$ & $-80,224$ & $-79,704$ & $-50,118$ & $-52,999$ & $-360,95$ \\
\hline Loja Y Cuenca & $-55,028$ & $-51,998$ & $-2,608$ & $-37,599$ & $-54,385$ & $-201,61$ \\
\hline Net Lima & 239,050 & 770,451 & $1,006,596$ & $-1,497,947$ & 512,388 & $1,030,53$ \\
\hline
\end{tabular}

Table 4 Net transfers between Spanish American treasuries 1796-1800, Spanish pesos.

\begin{tabular}{|c|c|c|c|c|c|c|}
\hline Caja & 1796 & 1797 & 1798 & 1799 & 1800 & 1796-1800 \\
\hline Acapulco & 9,068 & $-221,546$ & 111,887 & 760,174 & 0 & 659,583 \\
\hline Arispe & 7,991 & 121,930 & $-31,208$ & 38,394 & $-74,294$ & 62,813 \\
\hline Bolaños & $-166,354$ & $-175,024$ & $-92,886$ & $-119,258$ & $-52,739$ & $-606,261$ \\
\hline ampeche & 129,415 & 109,817 & 48,526 & 0 & & 287,758 \\
\hline hua & & 369,617 & $-144,673$ & $-119,688$ & $-289,459$ & 193,203 \\
\hline urango & $-414,352$ & $-438,907$ & $-362,254$ & $-451,617$ & $-340,939$ & $-2,008,069$ \\
\hline ajara & $-891,158$ & -794 & $-674,100$ & $-798,555$ & -604, & $-3,76$ \\
\hline juato & $-815,528$ & $-1,094,892$ & $-772,979$ & $-1,040,253$ & $-733,942$ & $-4,457,594$ \\
\hline Merida & $-38,930-$ & 0 & $-53,524$ & 104,847 & $-8,288$ & 4,105 \\
\hline Mexico & $-2,642,896$ & $-414,447$ & $5,654,864$ & $-5,688,342$ & 6,604,538 & $-21,005,087$ \\
\hline Michoacan & 0 & 11 & 344 & $-5,565$ & 6,286 & 1,076 \\
\hline Daxaca & $-100,474$ & $-207,347$ & $-408,265$ & $-366,776$ & $-255,236$ & $-1,338,098$ \\
\hline Pachuca & $-151,935$ & $-67,284$ & $-88,606$ & $-15,727$ & $-110,340$ & $-433,892$ \\
\hline Pres del Carmen & 58,279 & $-11,467$ & 0 & & -902 & 37,791 \\
\hline Duebla & 24,822 & $-470,506$ & -22 & $-2,461$ & 78,338 & $-369,829$ \\
\hline Rosario & $-295,668$ & $-292,644$ & $-203,929$ & $-868,596$ & 32,560 & $-1,628,277$ \\
\hline Saltillo & $-248,105$ & $-197,054$ & $-278,672$ & $-259,239$ & $-783,818$ & $-1,766,978$ \\
\hline San Luis Potosi & $-1,038,626$ & $-815,608$ & $-704,412$ & $-785,, 869$ & & $-3,344,, 515$ \\
\hline Sombrerete & $-211,103$ & $-141,744$ & $-228,691$ & $-169,416$ & $-140,736$ & $-891,690$ \\
\hline Tabasco & $-6,379$ & 0 & 0 & 0 & 0 & $-6,379$ \\
\hline /e & $-304,122$ & 505,737 & 300,078 & $-1,175,557$ & $2,438,954$ & $1,765,090$ \\
\hline
\end{tabular}




\begin{tabular}{|c|c|c|c|c|c|c|}
\hline Zacatecas & $-711,042$ & $-858,119$ & $-704,891$ & $-750,685$ & $-700,194$ & $-3,724,931$ \\
\hline Zimapan & $-144,277$ & $-164,511$ & $-113,198$ & $-94,895$ & $-78,124$ & $-595,005$ \\
\hline Net New Spain & $-7,951,374$ & $-5,258,063$ & $-10,056,429$ & $11,809,084$ & $-8,238,838$ & $-43,313,788$ \\
\hline Potosi & 435,755 & 265191 & 36041 & 54778 & 39990 & 831755 \\
\hline Charcas & 0 & 0 & 0 & & 0 & 0 \\
\hline La Paz & 0 & 0 & $-421,506$ & $-156,500$ & $-566,518$ & $-1,144,524$ \\
\hline Oruro & 110,753 & & $-99,395$ & $-84,465$ & $-30,000$ & $-324,613$ \\
\hline Arica & $-49,396$ & $-65,582$ & $-78,575$ & $-54,776$ & $-58,762$ & $-307,091$ \\
\hline Carangas & $-6,857$ & $-11,934$ & $-34,427$ & $-17,000$ & $-28,022$ & $-98,240$ \\
\hline Cochabamba & 0 & 0 & 0 & 0 & 0 & 0 \\
\hline Chucuito & & & $-149,388$ & & $-240,146$ & $-389,, 534$ \\
\hline Sta Cruz de la S. & 0 & 0 & 0 & 0 & 0 & 0 \\
\hline Net Upper Peru & 268,749 & 187,675 & $-747,250$ & $-2,579,63$ & $-883,458$ & $-1,432,247$ \\
\hline Santiago de Chile & 0 & 0 & 0 & 0 & 0 & 0 \\
\hline Valdavia & 96,141 & 106,815 & 49,061 & 37,298 & 54,288 & 343,603 \\
\hline Concepción & 0 & 0 & 0 & 0 & 0 & 0 \\
\hline Mendoza & 0 & 0 & $-3,185$ & $-1,974$ & $-1,907$ & $-7,066$ \\
\hline Chiloe & 20,032 & 12,953 & $-1,759$ & $-7,213$ & $-6,574$ & 17,439 \\
\hline Net Chile & 116,173 & 119,768 & 44,117 & 28,111 & 45,807 & 353,976 \\
\hline Buenos Aires & $1,111,678$ & $1,242,167$ & $1,456,001$ & $1,034,544$ & $2,317,940$ & $7,162,330$ \\
\hline Montevideo & 42,897 & 99,984 & 85,387 & 67,926 & 219,550 & 515,744 \\
\hline Catamarca & 0 & & & $-5,000$ & 0 & $-5,000$ \\
\hline Cordoba & 0 & 0 & 0 & 0 & $-12,000$ & $-12,000$ \\
\hline Corrientes & -372 & $-1,442$ & $-1,000$ & 0 & 0 & $-2,814$ \\
\hline La Rioja & & & $-1,184$ & 0 & 0 & $-1,184$ \\
\hline Maldonado & 45,358 & 29,324 & 29,875 & 12,714 & 107,978 & 225,249 \\
\hline Paraguay & 56,135 & 0 & 0 & 51,897 & 28,463 & 136,495 \\
\hline Salta & 0 & 0 & 0 & 0 & 0 & 0 \\
\hline San Juan & 37 & & 0 & & & 37 \\
\hline Santa Fe & 3,972 & $-5,671$ & $-3,505$ & $-2,273$ & 755 & $-6,722$ \\
\hline Santiago d Estero & 0 & 0 & 0 & 0 & 0 & 0 \\
\hline Tucumán & $-3,639$ & 0 & 0 & 0 & 0 & $-3,639$ \\
\hline Net River Plate & $1,256,066$ & $1,364,362$ & $1,565,574$ & $1,159,808$ & $2,662,686$ & $8,008,496$ \\
\hline Arequipa & $-98,886$ & $-274,253$ & $-83,855$ & $-56,135$ & $-116,232$ & $-629,361$ \\
\hline Carabaya & $-91,991$ & & & & & $-91,991$ \\
\hline Cuzco & $-181,581$ & $-211,038$ & $-160,433$ & $-81,356$ & $-194,993$ & $-829,401$ \\
\hline Huamanga & $-149,952$ & $-106,126$ & $-129,212$ & $-147,637$ & $-119,982$ & $-652,909$ \\
\hline \multicolumn{7}{|l|}{ Jauja } \\
\hline Lima & $1,491,660$ & $1,507,814$ & $1,293,636$ & $1,132,459$ & $1,289,277$ & $6,714,846$ \\
\hline Trujillo & $-167,346$ & $-202,616$ & $-158,675$ & $-207,488$ & $-168,441$ & $-904,566$ \\
\hline Vico Y Pasco & $-444,014$ & $-368,322$ & $-481,353$ & $-399,684$ & $-37,001$ & $-1,730,374$ \\
\hline Quito & $-59,616$ & $-75,797$ & $-63,199$ & $-119,326$ & $-98,412$ & $-416,350$ \\
\hline Guayaquil & $-16,340$ & $-22,613$ & $-48,817$ & $-8,140$ & & $-95,910$ \\
\hline Loja Y Cuenca & $-70,326$ & $-65,747$ & $-65,285$ & $-52,307$ & $-49,564$ & $-303,229$ \\
\hline Net Lima & 211,608 & 181,302 & 102,807 & 60386 & 504,652 & $1,060,755$ \\
\hline
\end{tabular}

Note: cells in blank $=$ no data 


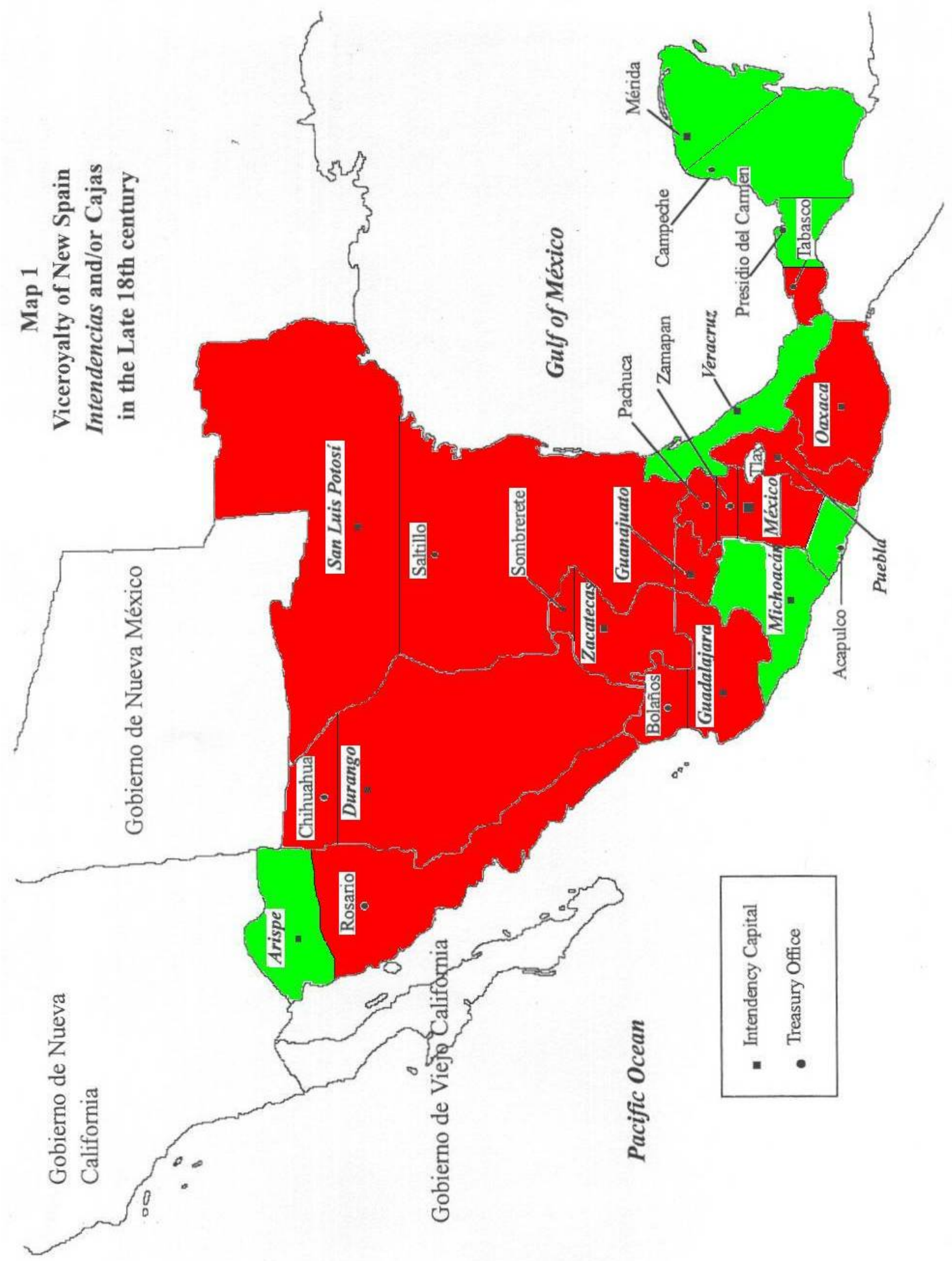




\section{Map 2:}

Viceroyalty of Peru \& Audiencia of Charcas

Trujillo

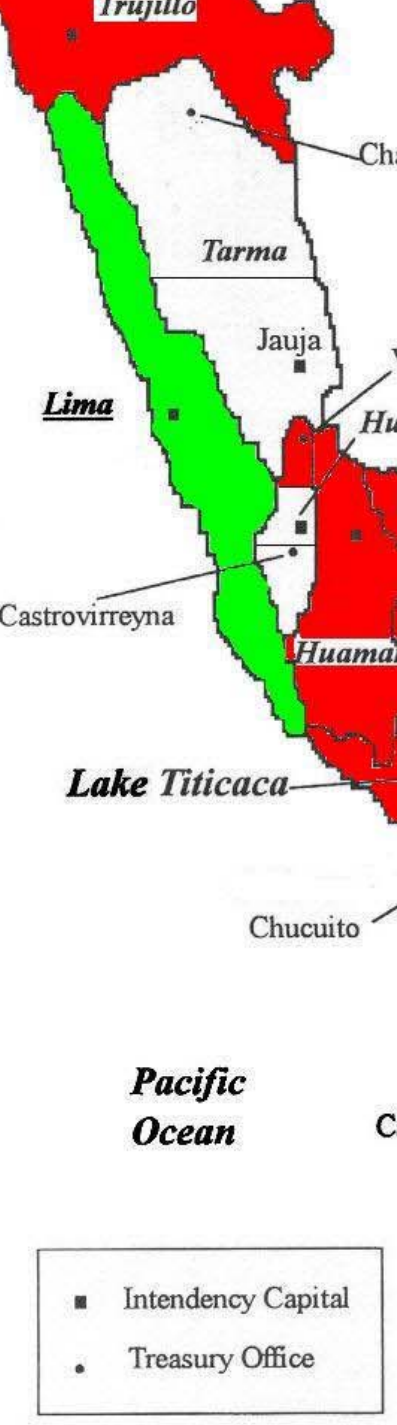

Intendencies and/or Principal Treasuries in the late Eighteenth Century 


\section{References:}

Acemoglu, Daron, Simon Johnson, and James Robinson. "The colonial origins of comparative development: An empirical investigation." American Economic Review 91 (2001): 1369-1401.

__. "Institutional Causes, Macroeconomic Symptoms: volatility, crises and growth." NBER working paper, no. 9124 (2002).

—. "Reversal of Fortune: Geography and Institutions in the Making of the Modern World Income Distribution." Quarterly Journal of Economics (2002).

Assadourian, Carlos Sempat. El sistema de la económia colonial. El mercado interior, regiones y espacio económico. México: Editorial Nueva Imagen, 1983.

Barbier, Jacques A., and Herbert S. Klein. "Revolutionary Wars and Public Finances: The Madrid Treasury, 1784-1807." Journal of Economic History 41, no. 2 (1981): 315-39.

Bértola, Luis, and Jeffrey G. Williamson. "Globalization in Latin America before 1940." NBER working paper 9687 (2003).

Bethell, L., and N. Macaulay. The emergence of Latin America in the nineteenth century. Oxford: Oxford University Press, 1994.

Brown, K.W. "Price Movements in 18th century Peru - Arequipa." In Essays on the price history of 18th century Latin America, edited by Lyman L. Johnson and Enrique Tandeter. Albuquerque: University of New Mexico, 1990.

Bushnell, David, and N. Macaulay. Emergence of Latin America in the 19th century. Oxford: Oxford University Press, 1994.

Centeno, M. A. "Blood and Debt. War and Taxation in nineteenth century Latin America." American Journal of Sociology 103, no. May (1997): 1565-1605. 
Coatsworth, J. "Economic and Institutional Trajectories in Latin America." In Latin America and the World Economy since 1800, edited by J. Coatsworth and A.M. Taylor. Cambridge/MA: Harvard University Press, 1998.

Coatsworth, J., and Jeffrey G Williamson. "Always protectionist? Latin American tariffs from Independence to Great Depression." Journal of Latin American Studies 36, no. 2 (2004): 205-232.

de la Sagra, Ramon. Historia económica, política y estadística de la isla de Cuba or sea de sus progresos en la población, la agricultura, el comercio ys las rentas. Habana: Imprenta de las Viudas de Arazoza y Soler, impresoras del gobierno y capitania general, de la Real Hacienda y de la Real Sociedad Patriotica por S.M., 1831. De Long, Brad, and Andrei Shleifer. "Princes or Merchants. European City Growth before the Industrial Revolution." Journal of Law and Economics 36 (1983): 671-702.

Diamond, J. Guns, Germs and Steel. New York: W.W.Norton \& Co, 1997. Dobado, Rafael. "El Monopolio estatal del mercurio en Nueva Espana durante el siglo dieciocho." Hispanic American Historical Review 82, no. 4 (2002): 685-718.

Earle Mond, Rebecca. "Indian Rebellion and Bourbon Reform in Granada. Riots in Pasto 1780-1800." Hispanic American Historical Review 73, no. 1 (1993): 99-124.

Easterly, William, and W. Levine. "Tropics, Germs, and Crops: How Endowments Influence Economic Development." Journal of Monetary Economics 50 (2003): 3-40.

Elliott, J.H. "Empire and state in British and Spanish America." In Le Nouveau Monde. Mondes Nouveaux. L'experience américaine, edited by Serge Gruzinski and Nathan Wachtel. Paris, 1996.

Engerman, S., and K. Sokoloff. "The Evolution of Suffrage Institutions in the New World." NBER working paper, no. 8512 (2001). 
_. "Institutional and Non-Institutional Explanations of Economic Differences." NBER working paper, no. 9989 (2003).

Engerman, Stanley L., and Kenneth L. Sokoloff. "Colonialism, Inequality, and Long-Run Path of Development." NBER working paper 11057 (2005).

Gallup, J.L., Jeffrey D. Sachs, and A.D. Mellinger. "Geography and Economic Development." NBER working paper 6849 (1998).

Gallup, John Luke, Alejandro Gaviria, and Eduardo Lora. Is Geography Destiny? Lessons from Latin America. Stanford: Stanford University Press and Inter-American Development Bank, 2003.

Garner, Richard L. "Long Term Silver Mining Trends in Spanish America. A Comparative Analysis of Peru and Mexico." The American Historical Review 93, no. 4 (1988): 898-935.

Guerra, Francois-Xavier. "The Spanish American Tradition of Representation and Its European Roots." Journal of Latin American Studies 26, no. 1 (1994): 1-35.

Haber, Stephen. "Introduction." In Political Institutions and Economic Growth in Latin America: Essays in policy, history and political economy, edited by Stephen Haber. Stanford: Stanford University Press, 2000.

Halperin Donghi, T. "The Crisis of Independence." In The Contemporary History of Latin America. Durham: Duke University Press, 1993. Halperín Donghi, Tulio. "Backward Looks and Forward Glimpses from a Quincentennial Vantage Point." Journal of Latin American Studies Supplement (1992): 219-234.

Hazard, Samuel, ed. The Register of Pennsylvania. Devoted to the Preservation of Facts and Documents, and every other kind of useful information respecting the State of Pennsylvania. Vol. 1. Philadelphia: W.F.Geddes, January to July 1828. 
Irigoin, Maria Alejandra. "Bringing the New World Back into Global History (The origins of another great divergence?) Spanish American silver bound for China on North American vessels 1780s-1820s." paper presented at DRCLAS Latin America History Workshop, Harvard (2005).

- "Macroeconomic aspects of Spanish American Independence.

The effects of fiscal and monetary fragmentation, 1800s-1860s."

Universidad Carlos III, Depto de Historia Económica working paper, no. 03/25 (09) (2003).

Irigoin, Maria Alejandra, and Regina Grafe. "Bargaining for Absolutism. A Spanish Path to Empire and Nation Building." University of Oxford. Discussion Papers in Economic and Social History (forthcoming). Jago, Charles J. "Habsburg Absolutism and the Cortes of Castile." American Historical Review 86 (1981): 307-326.

Jara, A. "Las Conexiones e Intercambios Americanos con el Oriente bajo el marco Imperial Español." In European Entry into the Pacific. Spain and the Acapulco - Manila Galleons, edited by Dennis O. Flynn, Arturo Giráldez and James Sobrado. Aldershot: Ashgate, 2001.

Jaramillo, J., Adolfo Meisel, and M. Urrutia. "Continuities and Discontinuities in the Fiscal and Monetary Institutions of New Granada." In Transfering Wealth and Power from the Old to the New World, edited by Michael D Bordo and Roberto Cortes-Conde, 414-47. New York: Cambridge University Press, 2001.

Johnson, Lyman L., and Susan Migden Socolow. "Colonial centers, colonial peripheries, and the agency of the Spanish state." In Negotiated Empires. Centers and Peripheries in the Americas, 1500-1820, edited by Christine Daniels and Michael V. Kennedy, 59-77. New York and London: Routledge, 2002. 
Klein, Herbert S. The American Finances of the Spanish Empire. Royal Income and Expenditures in Colonial Mexico, Peru, and Bolivia, 1680-1809. Albuquerque: University of New Mexico Press, 1998.

Kuethe, Allen J. Military Reform and Society in New Granada, 1773-1808. Gainesville, 1978.

Lockhart, James, and Stuart Schwartz. Early Latin America. A history of colonial Spanish America and Brazil. Cambridge: Cambridge University Press, 1983.

Lynch, John. The Colonial Roots of Latin American Independence, Latin America between Colony and Nation. London: Palgrave, 2001.

_. "The Institutional Framework of Colonial Spanish America." Journal of Latin American Studies 24 (1992): 69-81.

Mackay, R. The Limits of Royal Authority. Resistance and Obedience in Seventeenth Century Castile. Cambridge, 1999.

Maclachlan, Jean O. Trade and Peace with Old Spain. New York: Octagon, 1974.

Mahoney, James. "Long-Run Development and the Legacy of Colonialism in Spanish America." American Journal of Sociology 109, no. 1 (2003): 50-106.

Marichal, Carlos. La bancarrota del virreinato: Nueva Espana y la las finanzas del imperio espanol 1780-1810. Mexico, 1999.

Marichal, Carlos, and Matilde Souto Mantecón. "Silver and Situados: New Spain and the Financing of the Spanish Empire in the Caribbean in the Eighteenth Century." Hispanic American Historical Review 74, no. 4 (1994): 587-613.

Meisel, Adolfo. "Subsidy-led growth in a fortified town: Cartagena de Indias and the Situado, 1751-1810." paper presented at LACLIO 2000 (2000).

Nader, H. Liberty in Absolutist Spain. The Habsburg Sale of Towns, 15161700. Baltimore and London, 1990. 
Newland, Carlos. "La presión fiscal en el espacio peruano, 1691-1790." mimeo Buenos Aires (2002).

North, Douglas C., and Barry R. Weingast. "Constitutions and Commitment: The Evolution of Institutions Governing Public Choice in Seventeenth-Century England." Journal of Economic History XLIX, no. 4 (1989): 803-832.

North, Douglass C. "Institutions and Economic Growth: An Historical Introduction." World Development 17, no. 9 (1989): 1319-1332.

North, Douglass C., Barry R. Weingast, and W. Summerhill. "Order, Disorder and Economic Change. Latin America verus North America." In Governing for Prosperity, edited by B. Bueno de Mesquita and H.L. Root. New Haven, 2000.

O'Phelan Godoy, Scarlett. "Las reformas fiscales borbonicas y su impacto en la sociedad colonial del bajo y alto Peru." In The economies of Mexico and Peru during the late colonial period, 1760-1810, edited by N Jacobsen and H.J. Pule, 341-356. Berlin: Colloquium Verlag, 1996.

—. Un siglo de rebeliones anticoloniales. Peru y Bolivia 1700-83.

Cuzco: Centro Bartolome de las Casas, 1988.

Phelan, John Leddy. "Authority and Flexibility in the Spanish Imperial Bureaucracy." (1967).

Prados de la Escosura, Leandro. "Colonial Independence and Economic Backwardness in Latin America." Carlos III Depto de Historia Económica working paper, no. 04/65 (03) (2004).

Ringrose, David R. Spain, Europe, and the "Spanish Miracle," 1700-1900.

Cambrdige and New York: Cambridge University Press, 1996.

Rodriguez O, J. Independence of Spanish America. Cambridge:

Cambridge University Press, 1998.

Rodrik, Dani, Arvind Subramanian, and Francesco Trebbi. "Institutions Rule: The Primacy of Institutions Over Geography and Integration 
in Economic Development." Journal of Economic Growth 9 (2004): 131-165.

Sachs, Jeffrey D. "Institutions Don't Rule: Direct Effect of Geography on Per Capita Income." NBER working paper 9490 (2003).

Safford, Frank. "Politics, Ideology and Society," in Spanish America after Independence, c 1820-c 1870." In Spanish America after Independence, c.1820-c.1879, edited by L Bethell. Cambridge: Cambridge University Press, 1987.

Slicher van Bath, B.H. Real Hacienda y economía en Hispanoamérica, 1541-1820. Amsterdam: CEDLA, 1989.

Sokoloff, K., and S. Engerman. "Institutions, Factor Endowments and Paths of Development in the New World." Journal of Economic Perspectives 14, no. 3 (2000): 217-232.

TePaske, J.J. "The financial disintegration of Royal Government of Mexico during the Epoch of Independence." In The Independence of Mexico and the Creation of the New Nation, edited by J. Rodriguez O. Los Angeles and Irvine: UCLA, 1989.

TePaske, John J. "New World Silver, Castile, and the Philippines, 15901800." In In Precious Metals in the Later Medieval and Early Modern Worlds, edited by John F. Richards. Durham, NC: Carolina Academic Press, 1983.

TePaske, John Jay. "Integral to Empire. The Vital Peripheries of Colonial Spanish America." In Negotiated Empires. Centers and Peripheries in the Americas, 1500-1820, edited by Christine Daniels and Michael V. Kennedy, 29-41. New York and London: Routledge, 2002.

TePaske, John, and Herbert Klein. The Royal Treasuries of the Spanish American Empire. Vol. 3 Chile and the Rio de la Plata: Duke University Press, 1982. 
Ternavasio, M. La revolución del voto. Política y elecciones en Buenos Aires, 1810-1852. Buenos Aires: Siglo XXI, 2002.

Thompson, I.A.A. "Absolutism in Castile." In Absolutism in SeventeenthCentury Europe, edited by J. Miller, 69-98. Basingstoke: Macmillan, 1990.

_. "The End of the Cortes of Castile." Parliaments, States and Representation 4, no. 2 (December) (1994).

Tovar Pinzon, Hermes. El imperio y sus colonias. Las cajas reales de la Nueva Granada en el siglo XVI. Bogota: Archivo General de la Nación, 1999.

US Bureau of the Census. Historical Statistics of the US, Old Series, Series B. Washington: US Government Printing Office, 1960. Historical Statistics of the US. Colonial Times to 1957, Series Y. Washington: US Government Printing Office. 
LONDON SCHOOL OF ECONOMICS

DEPARTMENT OF ECONOMIC HISTORY

WORKING PAPERS OF THE GLOBAL ECONOMIC HISTORY NETWORK (GEHN)

For further copies of this, and to see other titles in the department's group of working paper series, visit our website at:

http://www.Ise.ac.uk/collections/economichistory/

2004

01/04: State-Building, The Original Push For Institutional Changes in Modern China, 1840-1950

Kent Deng

02/04: The State and The Industrious Revolution in Tokugawa Japan

Kaoru Sugihara

03/04: $\quad$ Markets With, Without, and In Spite of States: West Africa in the Pre-colonial Nineteenth Century

Gareth Austin

04/04: The World Coffee Market in the Eighteenth and Nineteenth Centuries, from Colonial to National Regimes

Steven Topik

05/04: The Role of the Chinese State in Long-distance Commerce R. Bin Wong

06/04: Imperialism, Globalization, and Public Finance: The Case of Late Qing China

Harriet T. Zurndorfer

07/04: Japanese Imperialism in Global Resource History

Kaoru Sugihara

08/04: Colonies in a Globalizing Economy 1815-1948

Patrick Karl O'Brien 
09/05 States and Markets in Latin America: The Political Economy of Economic Interventionism

Colin M. Lewis

10/05 Global Independence and Economic Backwardness in Latin America

Leandro Prados de la Escosura

11/05 "Trust In God - But Tie Your Camel First." The Economic Organization Of The Trans-Saharan Slave Trade Between The Fourteenth And Nineteenth Centuries Sebastian Prange

12/05 Wu-Wei in Europe - A Study of Eurasian Economic Thought Christian Gerlach

13/05 Principal-Agent Problems in the French Slave Trade: The Case of Rochelais Armateurs and their Agents, 1763-1792 Albane Forestier

14/05 In What Way, and to What Degree, Did the Mughal State Inhibit Smithian Growth in India in the Seventeenth Century? Frank W. Ellis

15/05 Divided Interests, Divided Migrants. The Rationales of Policies Regarding Labour Mobility in Western Europe, c. 1550-1914 Anne Winter

16/05 Pre-Modern Economic Growth Revisited: Japan and the West

Osamu Saito

2006

17/06 Provincializing the First Industrial Revolution Patrick O'Brien

18/06 Shanghai-Based Industrialization in the Early $20^{\text {th }}$ Century: A Quantitative and Institutional Analysis

Debin Ma 
19/06 Imperialism, Globalization, and the Soap/Suds Industry in Republican China (1912-37): The Case of Unilever and the Chinese Consumer Harriet T. Zurndorfer

20/06 Melting Markets: The Rise and Decline of the AngloNorwegian Ice Trade, 1850-1920 Bodil Bjerkvik Blain

21/06 The Nature and Linkages of China's Tributary System under the Ming and Qing Dynasties

Giovanni Andornino

22/06 East and West: Textiles and Fashion in the Early Modern Period

Beverly Lemire \& Giorgio Riello

23/06 The Spanish Empire and Its Legacy: Fiscal Re-distribution and Political Conflict and Post-Colonial Spanish America Regina Grafe \& Maria Alejandra Irigoin 